\title{
O DEBATE PARLAMENTAR SOBRE A COMISSÃO NACIONAL DA VERDADE NO CONGRESSO NACIONAL BRASILEIRO
}

\section{Antonio Teixeira de Barros ${ }^{1}$}

(D) https://orcid.org/0000-0002-3061-8202

'Programa de Pós-Graduação do Centro de Formação da Câmara dos Deputados (Cefor), Brasília - DF, Brasil. E-mail: antonibarros@gmail.com.

DOI: $10.1590 / 3510401 / 2020$

\section{Introdução}

A criação da Comissão Nacional da Verdade (CNV) provocou controvérsias no Congresso Nacional brasileiro. Parlamentares se posicionaram a favor e contra a comissão, cada um com sua opiniáo apresentada como verdade política. Cabe lembrar a conhecida afirmação de Arendt (2000) de que, na política, a capacidade de formar opinião é fundamental, o que significa que a opinião é inerente às atividades políticas. A autora ressalta que na política se opera com um tipo próprio de verdade que não tem pretensão de validade universal, posto que se trata de um jogo de disputas de opinióes, sem o propósito de formular proposiçóes com validade universal, embora haja o objetivo de persuasão. É o que Giddens (1995) define como verdade hermenêutica, entendida como

Artigo recebido em: 08/02/2019

Aprovado em: 08/11/2019 aquela que é aberta a discussão, isto é, passível de controvérsias, em razão das várias possibilidades de interpretação.

Ao assumir que concordamos com esses argumentos, deixamos claro que acolhemos tais premissas para guiar o estudo aqui proposto. Isso porque nos inspiramos no argumento de que as lutas discursivas no Congresso Nacional sobre a CNV seguiram a lógica da verdade hermenêutica, pautada nas disputas de opiniáo, expressa nos pronunciamentos dos oradores. Defendemos ainda que os pronunciamentos e os discursos são fundamentais na atividade parlamentar, tendo em vista que o parlare é de notória relevância para a (des)construção dos regimes de verdade nos embates da política (Arnold, 1990; Miguel e Feitosa, 2009). Como afirma Moreira, o discurso "é um dos meios pelos quais a política se materializa” (2016, p. 12). Os debates e embates parlamentares contribuem, portanto, para a (re)produção de representaçóes do 
campo político (Waever, 2002). Por essa razão, os discursos podem ser considerados "a alma do processo legislativo" (Paiva, 2006, p. 31) e o parlamento, "o lugar por excelência do debate político e um palco aberto aos olhos dos públicos” (Landowski, 1977, p. 429). ${ }^{1}$

A função de parlar assume tanta importância na literatura que Heurtin (1999) refere-se ao espaço público parlamentar (l'espace public parlementaire), ao desvendar as razóes comunicativas dos legisladores. Para o autor, esse espaço público tão específico da democracia se estabelece pelo regime da visibilidade pública e da publicidade, uma espécie de praça pública ou "teatro de opinião" republicano, em que o único agente com poder de censura é o povo. Fora isso, a gramática do debate parlamentar é regida pela liberdade de expressão e de opinião e pela apresentação de argumentos e contra-argumentos, provas e contraprovas discursivas, em uma dinâmica que tem como objetivo maior o esclarecimento do público sobre as questôes em debate. A verdade e a mentira atuam no discurso parlamentar de forma ambígua, usadas estrategicamente como como dispositivos de legitimação discursiva, a depender de como são acionadas. Ambas podem ser usadas como formas de justificação contextualizada, ancoradas em crenças coletivas e expectativas sociais baseadas em valores socialmente compartilhados (Rodríguez, 2012, p. 131).

Esse breve preâmbulo tem como propósito situar a análise proposta neste artigo, cujo objetivo é estudar as lutas discursivas travadas por meio dos pronunciamentos parlamentares sobre a Comissão Nacional da Verdade (CNV), desde a apresentação do projeto de sua criação, em 2010 , até a finalização de suas atividades, em 2014. O corpus é formado por 512 pronunciamentos 416 de deputados e 96 de senadores. A proposta do Poder Executivo (projeto de lei n. 7 376/2010)² fazia parte do III Programa Nacional de Direitos Humanos (PNDH). ${ }^{3}$

Antes da análise dos pronunciamentos, apresentamos uma breve revisão bibliográfica sobre políticas da memória e justiça de transição; comissões da verdade versus políticas de reconciliação e anistia política.

\section{Políticas da memória e justiça de transição}

No estudo sobre as comissóes da verdade destacam-se duas perspectivas teóricas: as políticas da memória e a justiça de transição (Ramírez, Santelices e Suárez Madariaga, 2019; Romero e Hristova, 2019).

Na perspectiva das políticas da memória, os olhares para o passado e seu contínuo escrutínio tem como propósito promover o entendimento público com base em interpretaçóes dos atos de violaçóes de direitos. O resgate da memória é considerado, portanto, um instrumento para o ( $r$ )estabelecimento da verdade e, consequentemente, da justiça (Romanelli, 2015). Por políticas de memória, entende-se: "o conjunto de açóes dos estados para garantir processos individuais e coletivos de reparação que estabeleçam quais são os parâmetros éticos e morais que sustentam os regimes democráticos, desta forma combatendo-se todas as violaçóes aos Direitos Humanos cometidas no passado e as que ainda permanecem no presente" (Bauer, 2015, p. 120).

As políticas da memória implicam usos estratégicos e políticos do passado, em uma "batalha de memórias" (Schmidt, 2007, p. 133). Assim, o trabalho de memória funciona como dispositivo para combater o esquecimento, especialmente nos casos em que os fatos históricos são lidos e considerados a partir de visóes ideológicas hegemônicas que evidenciam e enfatizam certos aspectos, enquanto deixam outros de lado, negligenciando, assim, os direitos das vítimas à memória e à verdade. Afinal, "a memória, individual ou coletiva, é vulnerável a usos e manipulações" (Araújo e Santos, 2007, p. 98). Nesse caso, o trabalho de resgate da memória é complexo, amplo e extenso, incluindo a coleta de depoimentos, testemunhos pessoais, documentos e arquivos.

Tais políticas tentam estabelecer diferenças entre o tempo dos vencidos e o tempo dos vencedores. A premissa, com a qual concordamos, destaca que as fronteiras que delimitam as dimensões temporais são socialmente construídas. Isso implica uma dimensão política norteadora, que atribui valores diferenciados ao presente, ao passado e ao futuro, conforme o contexto e as circunstâncias sociopolíticas e culturais. Esse processo é condicionado também por ação ou omissão dos agentes políticos, o que justifica uma 
contínua problematização dos chamados tempo dos vencidos e tempo dos vencedores (Bauer, 2015).

$\mathrm{Na}$ perspectiva presenteísta, segundo Hartog (2013), o presente se transforma em passado e vice-versa. Assim, o passado é visto "não como um estado que já se deu, mas como algo que faz sentido num dar-se agora, num movimento de atualização, constituindo-se num campo de experiências possíveis para o pensamento e a interpretação" (Cardoso, 2001 , p. 20). Hartog problematiza os regimes de historicidade, entendendo-os como construçóes sociais do tempo sobre as diferentes experiências do tempo histórico que moldam e modelam formas de interpretação dessas experiências. Os regimes de historicidade funcionam, portanto, como dispositivos para enquadrar e circunscrever espaços simbólicos que demarcam os modos de escritura do tempo. O texto resultante desse processo estabelece uma ordem histórica "que permite e proíbe pensar certas coisas" (Hartog, 2013, p. 172). Em suma, um regime de historicidade "reformula e recicla os elementos anteriores da relação de tempo, a fim de fazer com que ele diga outra coisa, de outra maneira" (Idem, p. 172). Trata-se de um plano que fixa sentidos de longa duração na memória coletiva, supervalorizando o presente e esmaecendo a importância do passado.

No âmbito das políticas da memória, os estudos sobre a presença do passado no presente levaram os pesquisadores a criar expressões como "interdiçóes do passado", "passados presentes", "passados eternos", "passados que não passam”, "passados inexpiados", "presentes eternos" ou "passados estendidos". Tais termos são oriundos das frequentes problematizações sobre as tensôes existentes entre as noçóes de tempo e as de temporalidade, bem como de sua relação com situaçôes críticas (Bauer, 2015). No Brasil, por exemplo, o problema dos desaparecidos políticos e a continuidade da ditadura na democracia "configuram no caso brasileiro uma ausência de ruptura entre passado e presente, coexistindo no tempo cronológico e serial um paralelismo, uma simultaneidade na qual aglutinam-se fantasias, distorçôes, mitos e mentiras" (Idem, p. 124).

Recuperação, reabilitação e reinterpretação da memória têm como propósito mostrar que é possível "(re)nomear os desaparecidos e (re)inscrevê-los na história do país, processando jurídica e simbolicamente esse passado" (Teles, 2012, p. 117). Trata-se de buscar no próprio passado elementos para (re)construir um novo horizonte analítico, com vistas à (re)construção de uma nova história. Dessa forma, estudar a CNV pressupõe "uma problematização sobre o tempo, mais especificamente, sobre a noção de presente enquanto construção - como lugar e como objeto de uma interpelação" (Bauer, 2015, p. 123).

Em termos contextuais, a criação da CNV está relacionada à resposta do Estado brasileiro à sentença dada pela Comissão Interamericana de Direitos Humanos (CIDH), da Organização dos Estados Americanos (OEA), no julgamento do caso de Guilherme Gomes Lund, ${ }^{4}$ em 2010, que ficou conhecida como "sentença do Araguaia" (Coimbra, 2013, p. 37). A referida comissão condenou o Estado brasileiro "a investigar, esclarecer e responsabilizar seus agentes que participaram do desaparecimento de mais de 70 opositores políticos na repressão contra a Guerrilha do Araguaia" (Idem, p. 38). A sentença foi estendida aos vários casos de mortos e desaparecidos políticos na região do Araguaia (Pará, Maranhão e Tocantins) durante a repressão militar. A condenação teve como justificativa o fato de o Brasil ter violado a Convençáo Americana de Direitos Humanos, de 1969. O prazo estabelecido para o Brasil tomar providências em relação à sentença foi de um ano, o que motivou a apresentação do projeto de criação da $\mathrm{CNV}$, em regime de urgência urgentíssima (Coimbra, 2013).

O regime de urgência urgentíssima é criticado por Teles (2018, pp. 33-34) porque teve como resultado uma iniciativa improvisada em razáo do debate apressado, fruto da dispensa das formalidades regimentais. Para o autor, a tramitação acelerada da proposta prejudicou o potencial efetivo da CNV em termos de apuração dos fatos. Outra crítica feita por Coimbra (2013) e Teles (2010) foi a falta de participação dos movimentos sociais no debate. Assim, desconsiderou-se a perspectiva de que os movimentos sociais, "ocupam novos lugares nas democracias, ao ser incluído nas convençôes, falas dos especialistas e nas políticas públicas" (Teles, 2012, p. 57). Outro aspecto criticado por esses autores diz respeito à metodologia de trabalho contida na proposta final de criação da CNV. Por conta da resistência das Forças Armadas, 
o período de apuração foi ampliado de 1946 a 1988, evitando o foco específico no regime de exceção que vigorou entre 1964 e 1985. Além disso, a composição da CNV foi considerada reduzida, tendo em vista a amplitude das investigaçóes e seu período de apenas dois anos. Por fim, convém ressaltar que a $\mathrm{CNV}$ não pode atuar com efetiva autonomia para sugerir recomendações de responsabilização dos criminosos com base nas investigaçôes.

Além do viés de políticas de memória, a criação da CNV insere-se também na perspectiva de justiça de transição, ${ }^{5}$ um campo que defende a combinação de vários elementos, como a reflexão histórica, a intervenção pública e o desenvolvimento de uma consciência pública sobre as conjunturas críticas marcadas pelo legado de regimes autoritários, guerras e outras formas violência política (Hollanda, 2018, p. 2).

Soares acrescenta que a justiça de transição é conceituada como "o conjunto de abordagens, mecanismos (judiciais e não judiciais) e estratégias para enfrentar o legado de violência em massa do passado, atribuir responsabilidades, exigir a efetividade do direito à memória e à verdade, fortalecer as instituiçóes com valores democráticos e garantir a não repetição das atrocidades" (2006, s.p.). Trata-se de um instituto típico da passagem de um regime político autoritário para outro baseado em valores democráticos e respeito aos direitos humanos. Assim, os princípios da justiça de transição objetivam a reparação de graves violações dos direitos humanos, com vistas ao restabelecimento da paz, da consolidação democrática e de uma cultura de respeito. Oliveira, por sua vez, entende que a instalação da CNV representa uma “vitória simbólica dos vencidos" (2011, p. 185), o que leva ao questionamento de a história ser sempre contada sob a óptica dos vencedores.

A institucionalização da justiça de transição no direito internacional vincula-se ao direito à verdade, que, de acordo com a CIDH, acarreta a obrigação dos Estados de investigar, esclarecer, julgar e punir os agentes diretamente responsáveis por casos de graves violaçóes de direitos humanos. Cabe ainda ao Estado, "dependendo das circunstâncias de cada caso, garantir o acesso à informação sobre graves violações de direitos humanos que se encontram em instalaçóes e arquivos estatais" (Fernandes, 2015, p. 722).
Complementando, Neves (2012, p. 157) destaca que esse tipo de justiça se baseia no direito básico à justificação pública do Estado e na imputação de responsabilidades, após rigorosa apuração da verdade. A literatura registra ainda que a justiça de transição contribui para o objetivo público de revelar as verdades até então ocultadas, a fim de preservar a memória coletiva (Soares e Quinalha, 2011). A finalidade é a implementação de reformas institucionais para evitar violaçôes futuras (Weichert, 2014).

Um dos focos da justiça de transição está na premissa de que as vítimas precisam ter voz e visibilidade (Fernandes, 2015). Ressalta-se, portanto, uma relaçâo intrínseca entre democracia e direitos humanos (Hollanda, 2018). O trabalho de memória sob a perspectiva das vítimas tem como foco a reconstituição do repertório de argumentos que foram historicamente marginalizados pelos opressores. Trata-se de uma reconstrução social simbólica, com a finalidade de ressignificar essa categoria na história política nacional, mediante o reconhecimento da legitimidade moral de seus argumentos, traumas e sofrimentos (Aydos e Figueiredo, 2013; Indursky e Mayorca, 2019).

A justiça de transição é entendida como um processo que vem adquirindo diferentes nuances ao longo do tempo. Em primeiro lugar, teve como foco as políticas de anistia, envolvendo tensóes e matizes na disputa em torno do significado desse termo. No caso brasileiro, de acordo com Abrão e Torelly (2012), a anistia aprovada pela legislação incorporou duas visões, fruto dessas disputas e representando a primeira fase delas: anistia como liberdade e anistia como impunidade. A segunda fase de tais disputas é caracterizada pelos autores por um movimento posterior que reivindicou medidas do Estado para o resgate da memória, da verdade e da dignidade das vítimas da ditadura, resultando na instalaçấo de programas oficiais para esse fim. A terceira fase surgiu mais recentemente como um movimento de insurgência histórica, agendando um processo de releitura e revisão da anistia e associando a verdade com a justiça. Nessa abordagem, ambos os termos são vistos como plurais e móveis, ou seja, envolvem diferentes visóes sobre verdade, anistia e justiça. Trata-se da etapa mais radical em termos de 
reivindicação de reparação dos direitos das vítimas e combate à impunidade.

O esforço deliberado para promover o esquecimento do passado serve a projetos históricos e ideológicos voltados para apagar ou deslegitimar a memória dos fracassos e distanciá-los ao máximo do tempo presente e dos projetos de futuro, em uma lógica de reafirmação da história dos vencedores (Safatle e Teles, 2010). Esse movimento beneficiou diretamente os agentes da repressão brasileira quando os anistiou, impondo o ocultamento e a negaçáo do protagonismo dos ativistas e militantes que atuaram contra a ditadura. Trata-se de uma operação de eliminação simbólica da história, e tais movimentos nem sequer tiveram o direito de serem reconhecidos e nomeados como sujeitos políticos (Safatle, 2014). É o que Abrão e Genro (2012) denominam instrumentalização autoritária da memória, em um regime de justiça de transição conservadora, que atende aos interesses dos adeptos das forças políticas reacionárias, alinhadas à perspectiva dos opressores (Guimarães e Starling, 2012).

A transiçáo implica um processo amplo, complexo e contínuo de consolidação dos regimes democráticos de forma densa. Vários aspectos estão envolvidos nesse processo, como: um rigoroso trabalho de reconstrução documental que permita o resgate da memória por meio de registros históricos e fontes orais/testemunhais; a (re)construção de uma cultura política alicerçada em valores democráticos; a formulação e execução de políticas públicas específicas que promovam o respeito, a igualdade e a liberdade; o fortalecimento de instituiçóes democráticas que funcionem como antídoto à eventual emergência de novos projetos autoritários (Arthur, 2011).

A justiça de transição, com seus diferentes matizes, faz parte de um amplo movimento internacional de defesa da dignidade e dos direitos humanos. Por um lado, tal movimento é considerado positivo por favorecer a consolidação da cultura democrática; por outro, apresenta limites e problemas, como o alinhamento às políticas neoliberais conduzidas pelos países do capitalismo central, especialmente os Estados Unidos (Guilhot, 2005). Assim, há risco de simplificação da noção de justiça de transição, resultando na visão de que bastaria a superação das ditaduras, o que deixaria o passado como algo intocável (Meister, 2012).

Em termos procedimentais, Cueva (2011) ressalta que as comissōes da verdade na América Latina apresentaram a tendência de seguir padróes legais consagrados, apesar da possibilidade de ajustes conforme a realidade local. Por um lado, o autor avalia como positiva tal sistematização, a fim de garantir credibilidade pública, porém, por outro lado, a padronização de procedimentos pode implicar riscos e limitaçóes, ao adotar fórmulas e receitas que resultaram de outras experiências históricas, similares em alguns aspectos, mas singulares em outros.

No caso do Brasil, questiona-se a longa e incompleta transição política para a democracia, o que contribuiu mais para o esquecimento e a negação que para a recuperação efetiva da memória das vítimas da violência política. Tal transição é vista, portanto, como uma espécie de diluição dos fatos na memória coletiva, com vistas ao esquecimento. Assim, expressóes como transição política ou abertura lenta, gradual e segura também devem ser problematizadas. Trata-se de um repertório político e ideológico que favoreceu mais os torturadores e algozes que o resgate da memória das vítimas. Afinal, tais expressóes são respaldadas em noções de tempo e temporalidade que enfatizam o tempo dos vencedores e não o tempo dos vencidos (Bauer, 2015, p. 133).

A transição da ditadura para o regime democrático no Brasil foi controlada e autorizada pelos militares (Fico, 2017; Reis, 2018), em um contexto de continuidade da cultura política autoritária (Motta, 2018). O debate público sobre a instalação da CNV gerou "guerras de memórias" baseadas em dois processos contraditórios. De um lado estavam os que negavam a existência da ditadura e, do outro, os que exigiam a reabilitação política das vítimas da tortura e da violência política do Estado e a responsabilização dos torturadores (Pereira, 2015).

Embora sejam tratadas separadamente na literatura, defendemos o argumento de que políticas de memória e justiça de transição se complementam, pois cada uma das perspectivas oferece contribuiçóes relevantes, porém incompletas. Nesse sentido, concordamos com a explicação de Abrão (2012) de que políticas de memória bem-sucedidas podem contribuir para a efetivação da 
justiça de transição. Além disso, argumentamos que a reparação dos direitos das vítimas e a punição dos violadores dos direitos humanos dependem de um amplo e cuidadoso trabalho de resgate da memória e de documentação histórica. Em suma, o direito à verdade e à justiça requer fundamentação histórica, o que está diretamente relacionado ao resultado de efetivas políticas de memória. Isso reforça nosso ponto de vista de que ambas são complementares.

\section{Comissóes da verdade versus políticas de reconciliaçáo e anistia política}

As comissóes da verdade brasileiras questionam o esquecimento imposto pela Lei da Anistia, ${ }^{6}$ que seguiu a lógica da chamada política de reconciliação. Em geral, pode-se definir comissóes da verdade como:

[...] corpos sem caráter jurídico que se difundiram a partir dos anos de 1980 em países recém egressos de regimes autoritários e guerras civis. Embora as comissóes variem com os contextos políticos e sociais a que se aplicam, em geral envolvem sessões públicas ou privadas de testemunho com pessoas identificadas como vítimas de violaçóes de direitos humanos por agentes de força de regimes passados ou milícias privadas, com ou sem articulação com governos (Hollanda, 2018, p. 14).

O movimento de reparação dos direitos humanos, baseado em uma recontextualização da "verdade", emerge vinculado a uma perspectiva de (re) habilitação política das vítimas e de suas perspectivas históricas. Esse foi o motor do programa de ação dessas comissóes no Brasil e em outros países. Tal habilitação política é baseada no resgate da verdade das vítimas, narrada por elas mesmas ou por seus familiares. Trata-se de um trabalho orientado por uma pedagogia política que tem a verdade como valor cívico. A premissa dessa pedagogia é orientada pela necessidade de revelação de eventos violentos que provocaram danos à ordem democrática e aos direitos humanos. Portanto, objetiva-se que a visibilidade de tais eventos provoque reflexão pública sobre o passado e sirva de alerta acerca da situação atual e das frequentes ameaças de retomada de projetos autoritários. Segundo Schmidt, no que tange às vítimas e aos familiares: "os inquestionáveis traumatismos pelos quais passaram parecem conferir o estatuto de prova às suas narrativas: o ter visto e, mais ainda, o ter sentido na pele os sofrimentos imputados pelos agentes da repressão os autoriza, aparentemente, a assumir a função de reescrever a história recente do país” (2007, p. 152).

Estabelecida a verdade, supóe-se que "estejam dadas as condições para superar a repetição de vícios passados. Estanca-se a espiral de violaçóes de direitos humanos, como se a verdade tivesse efeito 'profilático"' (Hollanda, 2018, p. 7). Convém ressaltar que "verdade", nesse contexto, não se opóe necessariamente a mentira ou inverdade, mas principalmente a esquecimento. Nesses casos, políticas voltadas para o esquecimento tornam-se um fenômeno oficial, posto que são formuladas e adotadas pelo próprio Estado.

No Brasil, a CNV é reconhecida como fruto do desenvolvimento da retomada das políticas de direitos humanos, as quais passaram a ser efetivadas como políticas de Estado após a criação do I Programa Nacional de Direitos Humanos (I PNDH), em 1996 (Adorno, 2010; Gallo, 2016). Além de atender ao dispositivo da Constituição de 1988, que confere ao Estado a função de promover e assegurar os direitos humanos, a iniciativa se deve ainda às recomendaçóes da declaração que resultou da Conferência Mundial sobre Direitos Humanos, realizada em Viena (Áustria), em 1993, acerca da implementação de políticas sólidas e continuadas de direitos humanos por países que fazem parte da Organização das Nações Unidas (ONU). O II PNDH foi lançado em 2002, com o objetivo de aperfeiçoar o primeiro, ambos gestados durante o governo de Fernando Henrique Cardoso (1995-2002). O III PNDH foi lançado na gestão de Luiz Inácio Lula da Silva (2003-2010) e é considerado o mais ousado e completo, o que também gerou mais críticas e controvérsias, especialmente por instituir o direito à memória e à verdade.

Assim, o III PNDH acolheu reivindicações históricas da sociedade civil no que se refere a:

[...] acesso aos arquivos da ditadura, pelo direito a tomar conhecimento do que se passou com aqueles 
que desapareceram ou foram mortos durante a ditadura e pela responsabilização daqueles que cometeram graves violaçóes de direitos humanos. Essas reivindicações estiveram presentes em todos os movimentos pela reconstrução da normalidade democrática, desde a edição de Brasil: Nunca Mais, na luta pela anistia, nas campanhas pelas Diretas-já e outros movimentos de afirmação de direitos (Adorno, 2010, p. 15, grifo do autor).

A criação da CNV insere-se em uma perspectiva paradoxal. Por um lado, pode ser compreendida como um instrumento de políticas de memória, voltada para a reabilitação política das vítimas; por outro, firma-se como meio para a implementação de uma ideologia de reconciliação, cujo foco é a reconstrução de representaçôes históricas sobre o passado. Na perspectiva de política da memória, o papel social que a CNV desempenha no Brasil "é essencialmente o de reconciliação do Estado com a sociedade, buscando construir uma memória social que traga a verdade e a justiça para todos que tiveram a violação dos direitos humanos nos períodos autoritários" (Canabarro, 2014, p. 230). Quanto aos direitos humanos, a conferência realizada em 1993 reafirmou princípios fundamentais, como indivisibilidade, universalidade, interdependência e inter-relação dos direitos humanos. $\mathrm{O}$ documento destacou ainda a necessidade de vínculo entre democracia, desenvolvimento humano e direitos civis (Koerner, 2003).

As primeiras iniciativas do Estado brasileiro relacionadas à formulação de políticas de memória "datam de meados da década de 1990, por pressão de grupos de familiares de mortos e desaparecidos e ex-presos e perseguidos políticos" (Bauer, 2015, p. 120). Dentre as primeiras iniciativas destacam-se a Comissão Especial sobre Mortos e Desaparecidos Políticos, criada em 1995, e a Comissão de Anistia, instituída em 2001. A primeira teve como objetivo identificar e reconhecer pessoas desaparecidas durante a repressão militar, em função de terem participado de atividades políticas. A segunda ficou responsável pelas políticas de reparação e memória das vítimas da ditadura. A CNV:
[...] tem antecedentes na experiência brasileira, cabendo lembrar que o marco zero da memória organizada sobre o legado da repressão foi o desdobramento das atividades da Comissão de Justiça e Paz da Arquidiocese de São Paulo, respaldadas pelo Cardeal D. Paulo Evaristo Arns e que levou ao Relato, publicado em 1985, Brasil: Nunca Mais (Lafer, 2012, s.p., grifo do autor).

Em 2008, a XI Conferência Nacional de Direitos Humanos aprovou a proposta de criar uma comissão da verdade e da justiça. No entanto, na elaboração do texto final do III PNDH, lançado em dezembro de 2009 pelo governo federal, o projeto sofreu alteração e foi retirado o termo "justiça" do nome. Ao se retirar a expressão "justiça”, o papel da comissão foi claramente reduzido. Tal supressão é avaliada como "estratégia para evitar ou dificultar a responsabilização e a punição dos agentes do Estado" (Teles, 2010, p. 14). Isso implicou "a negação à memória em sua acepção de direito à justiça ou pelo menos a resistência a que a memória se transforme nesse elemento propulsor de ações penais" (Ferreira, 2011, p. 116).

A Lei da Anistia, de 1979, é criticada por ter sido concebida como um instrumento de esquecimento e não de memória. Ao ignorar os crimes cometidos durante a ditadura, o Estado tratou o passado como algo vinculado apenas à esfera privada e não como um fenômeno coletivo (Lira, 2009, p. 72). Essa lei foi forjada sob a "ideologia da reconciliação" (Vinyes, 2009, p. 31), cujo eixo argumentativo estava na equivalência entre a violência cometida por agentes do Estado e as açóes dos grupos que usaram armas e táticas de guerrilha. Tal equiparação "permitia responsabilizar a todos pela violência do período e, assim, incentivar o esquecimento recíproco, através da desmemória e do silêncio, mas também da decretação da superação dos conflitos reais e simbólicos" (Bauer, 2015, p. 118).

Reis (2010) entende a referida lei como um dispositivo que representou a vitória dos vencedores, ao impor silêncio sobre a tortura e os torturadores e propor a reconciliação com os vencidos, negligenciando a apuração dos eventos críticos decorrentes da violência política praticada pelos agentes do Estado. Pereira (2015) aponta a lei como instrumento que serviu de 
pretexto para o movimento de negação do período autoritário, contribuindo para as dissimulaçóes das práticas, do pensamento e dos projetos autoritários no Brasil. Ao conceder anistia aos dois lados, a lei "estabelecia o controle do passado a partir de sua interdição, ou 'neutralização moral' [...] em se tratando da equiparação das responsabilidades pela violência, vetando o direito à verdade e, por consequência, o conhecimento dos fatos imbricados na ditadura civil-militar" (Bauer, 2015, p. 118). Desse modo, para Bauer:

[...] ao se considerar a ditadura como uma “página virada”, o direito à verdade foi protelado, pois também era considerado uma ameaça à interpretação da reciprocidade da anistia. A ideia de reconciliação presente na elaboração da Lei da Anistia não pressupóe uma elaboração do passado [...], mas sim seu encerramento (2015, p. 118).

Ao promover a diluição das responsabilidades, a Lei da Anistia também contribuiu para a postergação das obrigaçóes do Estado brasileiro no que se refere à apuração das violaçóes de direitos. A ideologia da reconciliação "é explicitada na noção de 'rejeição de confrontos inúteis' -, valorizando os 'pactos e acordos nacionais' que possibilitaram a redemocratização" (Bauer, 2015, p. 133). O conceito de reconciliação pode levar à compreensão de que se trata de uma forma de perdão dos torturadores, visando lhes assegurar impunidade (González, 2012, p. 5). A política de reconciliação é criticada porque foi articulada pelas forças políticas interessadas em evitar a punição dos torturadores, impondo a perspectiva da história dos vencedores e promovendo o esquecimento da memória das vítimas (Coimbra, 2013; Gasparotto e Padrós, 2010).

Segundo Vinyes (2009), as políticas de anistia, como políticas de esquecimento, impunham o apagamento da memória como um dever cívico, uma solução pacífica para pôr fim às memórias dos regimes ditatoriais. Para o autor, o espaço da memória é, por natureza, um campo de lutas políticas que se antagonizam no que se refere a leituras e interpretaçóes do passado. Enquanto uns reivindicam o direito de lembrar, outros defendem o esquecimento como estratégia para seguir em frente. No primeiro caso, a noção de passado apresenta conotaçáo de tempo historicamente (re)construído, algo passível de revisão; ao passo que no segundo, pressupóe-se que "o passado seria um ciclo histórico fechado, já concluso e simbolicamente apartado do tempo presente, que já está sob o signo do terminado" (Nora, 1993, p. 7).

Esse debate requer breve alusão às diferentes abordagens sobre memória e história. Nos discursos contemporâneos sobre memória política e verdade histórica, Vinyes (2009) argumenta que tem predominado a perspectiva mais alinhada à primeira, a exemplo do resgate de testemunhos de familiares das vítimas das ditaduras, em uma visão estética do testemunho, que acentua os dramas emocionais na forma de relatos das memórias dos horrores do passado. Tais memórias funcionam como tecnologias simbólicas que produzem o status de sujeito político das vítimas.

Retomando as contribuições de Nora (1993), as lutas mencionadas se inscrevem nas divergências entre memória e história. A memória é dinâmica, sempre carregada por grupos vivos e, nesse sentido, "está em permanente evolução, aberta à dialética da lembrança e do esquecimento, inconsciente de suas deformaçóes sucessivas, vulnerável a todos os usos e manipulaçóes, suscetível de longas latências e de repentinas revitalizaçóes" (Nora, 1993, p. 9). Trata-se de compreender a memória como trabalho artesanal, afetivo e vulnerável a diversas interferências contextuais. A história, por sua vez, é uma "representação do passado", ou seja, "uma reconstrução sempre problemática e incompleta do que não existe mais" (Idem, p. 9). A história constitui, portanto, o estudo da memória, no plano da longa duração, ou a memória historicizada com base na reconstrução intelectual.

Ricoeur (2007) afirma que a memória, inevitavelmente, está associada à imaginação, pois o lembrar é um ato imaginativo, pautado em seletividades e omissóes. A história, por sua vez, constitui uma forma estabelecida de conhecimento que se volta para a compreensão crítica do passado, com base em documentos ou na memória arquivada, que funciona como matriz da representação histórica e das narrativas historiográficas. As narrativas que resultam da interpretaçáo produzem dispositivos para o registro das experiências de duração, moldando narrativas, que se configuram na forma de memórias. 
Já na perspectiva de Halbwachs (2004a; 2004b), embora o ato de lembrar seja individual, a memória constitui um patrimônio coletivo, moldado pelas relaçôes sociais. Assim, faz parte de uma cultura imaterial que incorpora tradiçóes, crenças e valores de uma coletividade. A memória é vista, portanto, como uma complexa construção histórico-social, que articula de forma processual e negociada as dimensóes individuais e sociais, fruto da relação dos indivíduos com os grupos sociais de referência, cujas bases são os quadros sociais comuns, que por sua vez oferecem suporte e parâmetros simbólicos para a interpretação das experiências vividas no plano coletivo. $\mathrm{O}$ autor ressalta ainda que a construção social e os enquadramentos da memória alimentam-se de fontes históricas que passam pelo crivo de atores profissionalizados no estudo da história.

Le Goff (1990), por outro lado, salienta que tanto a memória como a história são caracterizadas pela dialética entre passado e presente, cada uma a sua maneira. Enquanto a subjetividade é a marca da relação da memória com o tempo passado, a história busca a objetividade por meio da análise dos fatos pelos historiadores, embora não haja neutralidade nesse trabalho. Na visão do autor, a memória é um fenômeno individual e psicológico, fruto das atualizaçóes das percepçóes de cada pessoa sobre os passados. Trata-se, pois, de uma forma de experiência interior e subjetiva. A história, a seu turno, resulta na construção de uma memória coletiva, corporificada em documentos. Assim, a tarefa da história é contribuir para recuperar e reavaliar os referenciais ancorados na memória subjetiva, a fim de evitar o esquecimento/apagamento dos fatos e acontecimentos de relevância social.

Como se percebe, as distinçóes de perspectivas entre os autores são evidentes, o que não invalida, a nosso ver, uma abordagem complementar entre memória e história no caso em estudo. Na sequência, passamos à análise do debate parlamentar sobre o tema em debate, buscando perceber como deputados e senadores se posicionaram sobre a CNV.

\section{Análise dos pronunciamentos}

Iniciamos a análise com um panorama dos pronunciamentos, os principais oradores e os partidos políticos que mais se destacaram no debate acerca da CNV. Na sequência dividimos a análise em tópicos, considerando a ordem de importância hierárquica que cada um dos temas adquiriu no debate, em termos de volume de pronunciamentos. Assim, temos a seguinte sucessão temática: (a) debates sobre a instalação da CNV; (b) pronunciamentos sobre o relatório final da CNV; (c) críticas ao comportamento dos militares; (d) discussão acerca da composição da CNV. ${ }^{7}$

As tabelas de 1 a 4 desta seção apresentam um panorama dos oradores com maior número de pronunciamentos, os partidos aos quais estavam vinculados à época, o gênero deles e os temas tratados no debate sobre a CNV. No caso da Câmara dos

Tabela 1

Oradores com mais Pronunciamentos (2011-2014)

\begin{tabular}{clccc}
\hline & DEPUTADOS & NÚMERO & PARTIDO & UF \\
\hline 1 & Jair Bolsonaro & 26 & PP & RJ \\
\hline 2 & Chico Alencar & 24 & PSOL & RJ \\
\hline 3 & Luiz Couto & 17 & PT & PB \\
\hline 4 & Erika Kokay & 14 & PT & DF \\
\hline 5 & Luiza Erundina & 13 & PSB & SP \\
\hline 6 & Ivan Valente & 11 & PSOL & SP \\
\hline 7 & Walmir Assunção & 9 & PT & BA \\
\hline 8 & Domingos Dutra & 9 & PT & MA \\
\hline 9 & Maria do Rosário & 8 & PT & RS \\
\hline 10 & Fernando Ferro & 7 & PT & PE \\
\hline 11 & Janete Capiberibe & 7 & PSB & AP \\
\hline 12 & Marco Maia & 7 & PT & RS \\
\hline 13 & Fátima Bezerra & 6 & PT & RN \\
\hline 14 & Jandira Feghali & 6 & PCdoB & RJ \\
\hline 15 & Amauri Teixeira & 6 & PT & BA \\
\hline 16 & Augusto Carvalho & 5 & PSB & DF \\
\hline 17 & Décio Lima & 5 & PT & SC \\
\hline 18 & Chico Lopes & 5 & PT & CE \\
\hline 19 & Paulo Teixeira & 5 & PT & SP \\
\hline & SENADORES & NÚMERO & PARTIDO & \\
\hline 1 & Eduardo Suplicy & 9 & PT & SP \\
\hline 2 & Randolfe Rodrigues & 6 & PSOL & AP \\
\hline 3 & Pedro Simon & 5 & PMDB & RS \\
\hline 4 & Paulo Paim & 5 & PT & RS \\
\hline 5 & Lídice da Mata & 5 & PT & BA \\
\hline 6 & Vanessa Grazziotin & 5 & PCdoB & AM \\
\hline & Elaçapropia & & & \\
\hline
\end{tabular}

Fonte: Elaboração própria com base no levantamento dos pronunciamentos. 
Tabela 2

Pronunciamentos por Legenda Partidária (2011-2014)

\begin{tabular}{ccccccc}
\hline PARTIDOS & $\begin{array}{c}\text { NÚMERO } \\
\text { NA CÂMARA }\end{array}$ & CÂMARA (\%) & $\begin{array}{c}\text { NÚMERO } \\
\text { NO SENADO }\end{array}$ & SENADO (\%) & TOTAL \\
\hline 1 & PT & 159 & 38,22 & 37 & 38,54 & $\mathbf{1 8 6}$ \\
\hline 2 & PP & 38 & 9,13 & 0 & 0 & $\mathbf{3 8}$ \\
\hline 3 & PSOL & 45 & 10,82 & 16 & 16,67 & $\mathbf{6 1}$ \\
\hline 4 & PSB & 43 & 10,34 & 11 & 11,46 & $\mathbf{5 4}$ \\
\hline 5 & PPS & 15 & 3,61 & 2 & 2,08 & $\mathbf{1 7}$ \\
\hline 6 & PCdoB & 35 & 8,41 & 5 & 5,21 & $\mathbf{4 0}$ \\
\hline 7 & PSD & 18 & 4,33 & 0 & 0 & $\mathbf{1 8}$ \\
\hline 8 & PMDB & 9 & 2,16 & 13 & 13,54 & $\mathbf{2 2}$ \\
\hline 9 & PSDB & 8 & 1,92 & 2 & 2,08 & $\mathbf{1 0}$ \\
\hline 10 & PDT & 14 & 3,37 & 3 & 3,13 & $\mathbf{1 7}$ \\
\hline 11 & DEM & 9 & 2,16 & 4 & 4,17 & $\mathbf{1 3}$ \\
\hline 12 & PTB & 3 & 0,72 & 3 & 3,13 & $\mathbf{6}$ \\
\hline 13 & PP & 8 & 1,92 & 0 & 0 & $\mathbf{8}$ \\
\hline 14 & PV & 7 & 1,68 & 0 & 0 & 7 \\
\hline 15 & PRB & 1 & 0,24 & 0 & 0 & $\mathbf{1}$ \\
\hline 16 & PR & 3 & 0,72 & 0 & 0 & $\mathbf{3}$ \\
\hline 17 & PMN & 1 & 0,24 & 0 & 0 & $\mathbf{1}$ \\
\hline & TOTAL & $\mathbf{4 1 6}$ & $\mathbf{1 0 0}$ & $\mathbf{9 6}$ & $\mathbf{1 0 0}$ & $\mathbf{5 1 2}$ \\
\hline
\end{tabular}

Fonte: Elaboraçáo própria com base no levantamento dos pronunciamentos.

Tabela 3

Gênero dos Oradores (2011-2014)

\begin{tabular}{lcccc}
\hline \multicolumn{1}{c}{ GÊNERO } & $\begin{array}{c}\text { NÚMERO NA } \\
\text { CÂMARA }\end{array}$ & CÂMARA (\%) & $\begin{array}{c}\text { NÚMERO NO } \\
\text { SENADO }\end{array}$ & SENADO (\%) \\
\hline Masculino & 106 & 82,61 & 35 & 80,25 \\
\hline Feminino & 16 & 17,39 & 16 & 19,75 \\
\hline TOTAL $^{10}$ & $\mathbf{1 2 2}$ & $\mathbf{1 0 0}$ & $\mathbf{5 1}$ & $\mathbf{1 0 0}$ \\
\hline
\end{tabular}

Fonte: Elaboração própria com base no levantamento dos pronunciamentos.

Tabela 4

Temas dos Pronunciamentos (2011-2014)

\begin{tabular}{lcccc}
\hline \multicolumn{1}{c}{ TEMAS } & $\begin{array}{c}\text { NÚMERO NA } \\
\text { CÂMARA }\end{array}$ & CÂMARA (\%) & $\begin{array}{c}\text { NÚMERO NO } \\
\text { SENADO }\end{array}$ & SENADO (\%) \\
\hline Instalação da CNV & 219 & 52,64 & 49 & 51,04 \\
\hline Relatório final da CNV & 98 & 23,56 & 27 & 28,13 \\
\hline Comportamento dos militares & 81 & 19,47 & 12 & 12,50 \\
\hline Composição da CNV & 18 & 4,33 & 8 & 8,33 \\
\hline TOTAL & $\mathbf{4 1 6}$ & $\mathbf{1 0 0}$ & $\mathbf{9 6}$ & $\mathbf{1 0 0}$ \\
\hline
\end{tabular}

Fonte: Elaboração própria com base no levantamento dos pronunciamentos.

Deputados, o deputado Jair Bolsonaro (PP-RJ) foi o que mais falou sobre a CNV, seguido de Chico Alencar (PSOL-RJ), Luiz Couto (PT-PR), Erika Kokay
(PT-CE), Luiza Erundina (PSB-SP) e Ivan Valente (PSOL-SP). No Senado Federal os mais ativos no debate foram Eduardo Suplicy (PT-SP) e Randolfe 
Rodrigues (PSOL-AP). Esses dados revelam como foi polarizada discussão na Câmara entre deputados de direita e esquerda, enquanto no Senado preponderou a abordagem dos parlamentares de esquerda.

Quanto às legendas, o maior número de pronunciamentos foi de parlamentares de PT, PSOL, PSB, ou seja, de centro-esquerda e esquerda. Cabe salientar que o PT estava no governo federal no período analisado e que a proposta de criação da CNV foi elaborada e apresentada pelo governo petista. Já os outros dois partidos apresentam uma trajetória de defesa dos direitos humanos. O PT assumiu a liderança das discussóes em um contexto amplamente favorável ao partido, que contava com a maior bancada na Câmara, com setenta deputados. Além disso, a proposta de criação da CNV foi apresentada por iniciativa de um governo do partido.

Considerando que as mulheres perfaziam um total de $10 \%$ das cadeiras do Congresso Nacional, a atuação delas no debate foi expressivo, com 19,75\%. Convém ressaltar o protagonismo das deputadas de PT, PSB e PCdoB nesse debate, com atuação intensa de Luiza Erundina, Maria do Rosário, Fátima Bezerra, Erika Kokay e Jandira Feghali.

A instalação da CNV e a apresentação do relatório final foram os dois aspectos mais destacados no debate, ou seja, o anúncio de instalação da comissão e o encerramento dos trabalhos. A fase de anúncio ocupa mais de $50 \%$ dos pronunciamentos. O detalhamento sobre como cada tema foi abordado é feito na sequência.

\section{Debate parlamentar sobre a instalação da CNV}

Em pronunciamento feito em 15 de maio de 2012, quando da instalação da CNV, o senador Eduardo Suplicy (PT-SP) disse que não se tratava "de vingança ou de revanchismo, mas de um diálogo democrático, que busca[va] elucidar a história recente de nosso País". A comissão tinha "por finalidade examinar e esclarecer as graves violações de direitos humanos praticados no período de 18 de setembro de 1946 a 5 de outubro de 1988, a fim de efetivar o direito à memória e à verdade histórica e promover a reconciliação nacional”. Para o senador, o objetivo da CNV era "promover o esclarecimento circunstanciado dos casos de torturas, mortes, desaparecimentos forçados, ocultação de cadáveres e sua autoria, ainda que ocorridos no exterior". O senador Paulo Paim (PT-RS), em fala no dia 24 de maio de 2012, complementou dizendo: "é preciso que tenhamos claro o sentido e o alcance da Comissão da Verdade. Não se trata aqui de revanchismo, não se trata de reabrir um processo já fechado, de mexer em feridas, não se trata de promover uma caça às bruxas". Segundo o senador, não se buscava "vingança, mas justiça, transparência e verdade”. Destacou ainda: "devemos lembrar que crimes de desaparecimento forçado de pessoas são crimes permanentes, jamais podemos apagar".

Outros senadores mencionaram a questão do revanchismo, em pronunciamentos realizados em 16 de maio de 2012, ao refutarem argumentos dos militares e dos partidos de direita. De acordo com o senador Antonio Carlos Valadares (PSB-SE), a CNV não seria "pautada pelo revanchismo nem pelo ódio. O Brasil merece a verdade". A senadora Marta Suplicy (PT-SP) afirmou: "Não cabe falar em revanchismo, e o próprio ato de instalação da Comissão da Verdade mostra que ela é, antes de tudo - e foi um ato muito forte -, um desejo nacional”.

Até aqui observa-se um argumento comum dos parlamentares de esquerda: a refutação da ideia de revanchismo. Convém salientar que esse tema constituía um dos pilares dos argumentos dos representantes da direita, quando ressaltavam que a CNV teria sido criada pelo governo do PT como um instrumento para a esquerda se vingar politicamente dos militares e das demais forças políticas que comandaram o regime de exceção (Pinto, 2010).

O pronunciamento da senadora Lídice da Mata (PT-BA) relacionou a busca da verdade política com transparência:

A Comissão foi instalada no mesmo dia em que entra em vigor a Lei de Acesso à Informação Pública, o que reforça sua atuação. O Brasil não pode continuar mais convivendo com o silêncio, a mentira e a dissimulação, nem com o fantasma que ronda a vida de centenas de famílias brasileiras que lutam por um direito elementar e sagrado: sepultar os corpos de seus entes queridos (16 maio 2012). 
Outros oradores relacionaram a CNV à construção de uma memória coletiva:

A Comissão tem o papel crucial de construir uma memória coletiva. É preciso acabar com o negacionismo militar sobre os crimes da ditadura (senador Paulo Paim, PT-RS, 24 maio 2012).

A Comissão é imprescindível para resgatar a memória nacional, para banir o fundamentalismo, a intolerância (deputada Janete Capiberibe, PSBAP, $1^{\circ}$ abr. 2013).

É importante agora, neste momento em que a democracia está restaurada, que nós recuperemos a memória do nosso povo, principalmente para que as novas gerações tenham o direito de conhecer a história do seu País (deputado Brizola Neto, PDT-RJ, 21 set. 2011).

Mais que a memória, os oradores ressaltaram a necessidade de uma revisão da história política, vinculando memória política e história:

Devemos repensar os livros de história. Isso é gerar a cultura da prática democrática e da paz, que não convive com a impunidade (senador Paulo Paim, PT-RS, 24 maio 2012).

É muito importante o trabalho desta Comissão para reconstruir a nossa história. Além de buscar a verdade, vai servir para informar o povo sobre aquele período, para que nunca mais aconteça (deputado Severino Ninho, PSB-PE, 16 maio 2012).

A Comissão procurará resgatar e passar a limpo a História do Brasil, e cada um de seus integrantes será responsável por esse momento histórico (deputada Benedita da Silva, PT-RJ, 16 maio 2012).
O futuro também foi apontado como um horizonte histórico a ser redimido por meio da recuperação da memória e da revisão da história política:

A Comissão deve se voltar para o futuro. Que levante minuciosamente e analise, de forma responsável e séria, tudo o que aconteceu no passado, mas com os olhos voltados para a democracia que nós queremos construir (deputado Alfredo Sirkis, PV-RJ, 22 set. 2011).

A Comissão deu um passo fundamental para que o Brasil, conseguindo olhar para o passado, possa construir um futuro diferente, sem violações de direitos humanos (deputado Alessandro Molon, PT-MG, 22 set. 2011).

Os discursos mencionados ressaltam a relação entre política e tempo histórico. Afinal, todos os processos políticos são regulados pelo tempo. Convém ressaltar que o tempo expressa uma rede de configuraçóes sociais em que estamos inseridos, bem como demarca escalas históricas da política e regula relaçóes sociais, sendo um elemento relevante no processo civilizatório e na experiência humana (Elias, 1989). As aproximaçóes entre passado, presente e futuro expressam uma relação dialética de proximidade e distanciamento com os fatos históricos em debate.

Os pronunciamentos destacados anteriormente evocam o passado como um farol simbólico que serve para iluminar o presente, deixando de ser um passado perdido e se tornando uma inspiração para motivar a construção de um futuro mais democrático e com mais respeito aos direitos humanos. Assim, o tempo histórico se reveste de sentido social e constrói ele próprio uma fonte de sentidos para as futuras gerações.

Desse modo, a maioria dos pronunciamentos se alinha à perspectiva de políticas da memória, abordada na primeira parte deste artigo, como um olhar para o passado a fim de produzir memória, verdade, justiça e reparação (Romanelli, 2015; Bauer, 2015), superando a hegemonia do esquecimento (Araújo e Santos, 2007) e dos "passados que não passam" ou "passados inexpiados" (Bauer, 2015, p. 123). Esse debate reflete diretamente o que a literatura anteriormente revisada denomina batalhas de memória, expressas nas lutas 
discursivas em torno das disputas pela fixação de novos sentidos públicos aos fatos do passado.

O reconhecimento das vítimas e a reparação dos danos morais, que fazem parte dessa lógica das políticas da memória, foram aspectos destacados nos pronunciamentos de alguns políticos:

A Comissão dá voz e visibilidade às vítimas, restaurando sua dignidade. A narrativa que se constrói a partir desse testemunho é muito importante para nossa identidade (senador Paulo Paim, PT-RS, 24 maio 2012).

A criação da CNV é uma obrigação moral e política que decorre do reconhecimento, pelo Estado brasileiro, de que ele teve, sim, responsabilidade por crimes cometidos durante a última ditadura e, por isso, deve esclarecimentos e reparação às famílias das vítimas (deputado Romário de Souza Faria, PSB-RJ, 14 mar. 2013).

As lágrimas, na solenidade de hoje, ao lembrar os mortos e desaparecidos políticos, foram da Nação brasileira, de centenas de mães, esposas, filhos, que lutam há anos pelo direito sagrado de enterrar seus entes queridos (senadora Lídice da Mata, PT-BA, 16 maio 2012).

É oportuno retomar neste ponto a ideia de Soares (2006) de que o reconhecimento das vítimas do terrorismo de Estado é um caminho para o fortalecimento da confiança cívica e do comprometimento do Estado democrático de direito com a efetividade dos direitos fundamentais e com os direitos humanos de modo geral.

Esse conjunto de pronunciamentos, ao ressaltar os direitos das vítimas à memória eà verdade, coloca em cena um dos focos da justiça de transição, representado pelo argumento de que as vítimas precisam ter visibilidade e voz (Araújo e Santos, 2007; Fernandes, 2015), acentuando a estreita relação entre democracia e direitos humanos (Hollanda, 2018). A defesa dos direitos das vítimas à verdade, à memória e à justiça constitui a terceira fase da justiça de transição, conforme foi abordado anteriormente (Abrão e Torelly, 2012). A ênfase está, portanto, na reparaçáo dos direitos das vítimas e no combate à impunidade com relação à violação dos direitos humanos.

A senadora Marta Suplicy (PT-SP), em fala no dia 16 de maio de 2012, destacou o papel didático da $\mathrm{CNV}$, que permite que a juventude brasileira, "que merece a verdade, tenha acesso à verdade factual, para conhecer a nossa história e formar suas opinióes". É preciso, então, "que os jovens se tornem cidadãos que não permitam a repetição dos erros cometidos". O mesmo aspecto foi enfatizado pelo deputado Glauber Braga (PSB-RJ), em 14 de março de 2013:

Não tenho dúvida de que a Comissão cumprirá um papel pedagógico e será um marco na defesa dos direitos humanos. Ela é de interesse não apenas dos familiares das vítimas, mas também do Parlamento, das Forças Armadas e da sociedade.

O que está implícito nos pronunciamentos destacados é que a (re)construção da memória coletiva e a redefinição das verdades históricas são processos de aprendizado coletivo pela via da socialização política, o que permite a (re)configuração de intersubjetividades. A memória é fundamental nesse processo, posto que funciona como farol hermenêutico para orientar condutas e práticas sociais "que tecem e mantêm os laços sociais", bem como guiam "a transformação dos valores dos grupos sociais”, em uma dinâmica relacional constante entre o social e o individual (Setton, 2013, pp. 198-199). A construção de uma cultura política democrática é apontada na literatura como ativo simbólico capaz de funcionar como antídoto a possíveis situações com tendência à instalação de regimes autoritários (Arthur, 2011; Motta, 2018).

Dois parlamentares usaram seus pronunciamentos para criticar a comissão, ambos com relaçóes de proximidade com as Forças Armadas:

Essa “Comissão da Patifaria” só serve para enxovalhar as Forças Armadas, que sempre estiveram do lado da democracia (deputado Jair Bolsonaro, PP-RJ, 10 out. 2012).

Essa Comissão é parte de um processo marxista, que tem prosseguimento em nosso País e que 
procura desmontar as estruturas de resistência ao marxismo em nosso País, desde 1964 (deputado Arolde de Oliveira, PSD-RS, 7 nov. 2012).

Deixe de perseguir os militares com essa tal Comissão da Verdade. Que Comissão é essa, Sra. Presidenta? A sua Comissão da Verdade é uma grande mentira (deputado Jair Bolsonaro, PP-RJ, 23 abr. 2013).

É importante mencionar que esses dois parlamentares mencionados são vinculados a forças políticas de direita, incluindo os militares. Jair Bolsonaro é capitão reformado do Exército e Arolde de Oliveira é oficial reformado do Exército. Ambos falam, portanto, para seus pares das Forças Armadas e para seu eleitorado conservador. Trata-se, desse modo, de um discurso político estratégico e de conveniência.

Outra observação pertinente é que tanto Jair Bolsonaro como Arolde de Oliveira usam estratégias retóricas que procuram desqualificar a CNV. A desqualificação no discurso político é vista como um conjunto de táticas que rejeitam e subestimam os valores preconizados pelos adversários, de modo a construir uma imagem positiva de si mesmo (ethos) e uma imagem negativa dos oponentes (Charaudeau, 2017). Esse tipo de argumentação também é denominado subestimação, ou seja, uma construção discursiva baseada em grandezas morais polarizadas e estigmatizadas. Seu propósito é engrandecer e supervalorizar a si e seus aliados ao mesmo tempo que mina as posiçóes contrárias, visando prejudicar a reputação dos adversários e persuadir o público a rejeitar a imagem, os argumentos e as propostas dos oponentes (Fantinati, 1990). Essa é a intenção dos dois parlamentares citados quando desqualificam a instalação oficial da CNV.

\section{Debate sobre o relatório final da comissáo}

Sobre o relatório final da CNV, o senador Eduardo Suplicy (PT-SP) afirmou: o trabalho conduzido permitiu à Comissão Nacional da Verdade concluir que as graves violaçóes a direitos humanos ocorridas no período investigado, especialmente nos 21 anos da ditadura instaurada em 1964, foram resultado de uma açáo generalizada e sistemática do Estado, configurando crimes contra a humanidade" (11 dez. 2014).

Um dia antes, o senador Randolfe Rodrigues (PSOL-AP) registrou: "o dia de hoje, 10 de dezembro de 2014, Dia Internacional dos Direitos Humanos, é o dia também em que a Comissão Nacional da Verdade concluiu os seus trabalhos". Ele ainda destacou que a conclusão dos trabalhos da CNV, "com a divulgação do seu relatório final, representa a vitória de todas as desconfianças que existiam sobre essa Comissão" (10 dez. 2014). Em tom de comemoração, o deputado Newton Lima (PT-SP) afirmou que o resultado do trabalho da comissão era "uma demonstração cabal da maturidade da nossa democracia, da nossa República e das nossas instituiçóes" (15 dez. 2014).

Ao discorrerem sobre o conteúdo do relatório, alguns parlamentares ressaltaram a natureza histórica do documento. O deputado Chico Alencar (PSOL-RJ) afirmou:

Trata-se de um importante documento histórico sobre as graves violaçôes de direitos humanos praticadas entre 1946 e 1988, em especial pela ditadura de 1964-1985 (11 dez. 2014).

Também foram ressaltadas as conclusões do relatório sobre as violaçôes de direitos humanos, um diagnóstico considerado politicamente positivo:

Dentre as violaçôes, são citadas prisões ilegais, torturas, violências sexuais, execuções e ocultação de cadáveres. Foram 1121 depoimentos, 132 deles de agentes públicos, 80 audiências e sessões públicas, que percorreram 20 Estados brasileiros (deputado Valmir Assunção, PT-BA, 10 dez. 2014).

O relatório descreve minuciosamente as violaçôes aos direitos humanos cometidas durante a ditadura 
militar. E, de forma inédita, elenca os agentes públicos responsáveis por essas violações, exigindo sua responsabilização (senador Lindbergh Farias, PT-RJ, 10 dez. 2014).

O relatório confirma tudo aquilo de que de alguma forma já sabíamos: a tortura no Brasil era uma política de Estado (deputado Ivan Valente, PSOL-SP, 10 dez. 2014).

Apesar de positivo, o direito à memória e à verdade foi considerado insuficiente por alguns oradores, que reivindicaram a inclusão da justiça, em uma demonstração de satisfação parcial com o resultado inicial, mas de insuficiência sob a óptica da reparação e da justiça:

Quero elogiar o trabalho da Comissão, que precisa se aprofundar, precisa fazer valer a justiça para além da memória e da verdade (deputada Jandira Feghali, PCdoB-RJ, 10 dez. 2014).

Concordo com a necessidade de criação de um órgão público que dê seguimento aos trabalhos, identificando mais vítimas, e seja executor de processos para impedir imposiçóes fascistas, violadoras de direitos (deputado Valmir Assunção, PT-BA, 10 dez. 2014).

Embora o relatório não mencionasse diretamente a revisão da Lei da Anistia, alguns parlamentares entenderam que era um momento oportuno para a revisão da referida lei, diante da conclusão dos trabalhos da CNV. Tal postura reflete o pensamento de uma vertente da esquerda brasileira que se mantém inconformada com a anistia dos torturadores. Para o deputado Valmir Assunção (PT-BA):

Não devemos temer o debate sobre a revisão da Lei de Anistia. Reparação histórica com a verdade significa punir os violadores de direitos humanos, punir quem torturou porque possuía privilégios, obtidos a partir de quem estava à frente do Estado (10 dez. 2014).
Apenas dois parlamentares criticaram o relatório final da CNV, os mesmos que se posicionaram contra a instalação da comissão, ambos com vínculo estreito com as Forças Armadas, conforme já mencionado. O deputado Jair Bolsonaro (PP-RJ) criticou o relatório $\mathrm{da} \mathrm{CNV}$ e disse que os militares merecem respeito porque “lutamos por democracia!". Dirigindo-se aos familiares de mortos e desaparecidos, falou:

Vocês deviam ter vergonha na cara, porque ou choravam vocês ou chorava toda a Nação brasileira, pois o Brasil estava mergulhando no comunismo. É difícil entender isso? A verdade é que tortura esses saudosos maoístas, esses saudosos bolcheviques, esses saudosos marxistas (11 dez. 2014).

O deputado Arolde de Oliveira (PSD-RJ), em 16 de dezembro de 2014, considerou como "parcial e revanchista o relatório final apresentado pela Comissão Nacional da Verdade”. Em razão disso, manifestou solidariedade ao general do Exército Sérgio Westphalen Etchegoyen,

pela manifestação de repúdio ao relatório da $\mathrm{CNV}$, que deixa cada vez mais claro o objetivo ideológico de revanchismo e de desconstrução da imagem das instituições militares.

O parlamentar expressou solidariedade também aos comandantes das Forças Armadas (Exército, Marinha e Aeronáutica),

pela colocação da relação dos 126 brasileiros que morreram lutando contra os revolucionários comunistas nos anos de 1960 e 1970 , e que foram absolutamente desprezados pelo relatório da Comissão a que estou aqui me referindo.

Por fim, acrescentou:

é triste vermos uma instituição, cuja missão era trazer a conciliaçáo ao povo brasileiro, apresentar um relatório que não tem nada a ver 
com os objetivos iniciais. Fica claro que existe um movimento de revanchismo, de inverdade por trás disso tudo.

Mais uma vez observa-se o uso de estratégias retóricas de desqualificação e subestimação do trabalho da CNV pelos parlamentares Jair Bolsonaro e Arolde de Oliveira. Ambos acusam o relatório final da CNV de revanchismo e de ser instrumento para prejudicar a reputação das Forças Armadas. Assim, repetem os mesmos argumentos, em uma redundância intencional que tem o objetivo de refutar as conclusóes do documento e diminuir sua importância. A manifestação de solidariedade aos comandantes das instituições militares mostra claramente a intenção de vinculação dos oradores às políticas de memória pautadas pela visão de anistia e esquecimento e defendidas pelos adeptos do regime de exceção.

O contraponto entre os defensores e os críticos do relatório da $\mathrm{CNV}$ confirma o pressuposto de que as políticas da memória e do esquecimento constituem, na realidade, uma "batalha de memórias" (Schmidt, 2007, p. 133), uma disputa discursiva entre o tempo dos vencidos e o tempo dos vencedores (Bauer, 2015, p. 124). O foco dessa disputa é a luta pelo monopólio da construção de interpretaçóes dos sentidos políticos do passado, a fim de transformar a memória em história (Cardoso, 2001, p. 20).

Nas disputas inerentes às batalhas de memória observa-se ainda que os parlamentares alinhados com o governo do PT se detiveram mais aos elogios que às críticas ao relatório da CNV, apesar dos reconhecidos limites do referido documento, conforme mencionado. Assim, ao serem pouco críticos, esses parlamentares atuaram com o intuito de legitimar o trabalho da CNV, como se fossem porta-vozes do governo, superestimando os resultados do trabalho da comissão. A superestimação, como recurso retórico no discurso político, é entendida como uma construção positiva do orador, com o propósito de fixar uma imagem favorável de si e de seu grupo. Nessa operação discursiva são ressaltados e supervalorizados os aspectos favoráveis, ao passo que eventuais pontos negativos e críticos são ocultados, dissimulados ou diminuídos e relativizados (Fantinati, 1990). Os parlamentares do PT e dos demais partidos da coalizão governamental fizeram isso ao engrandecer o relatório final da CNV e amenizar suas lacunas e críticas.

\section{Debate sobre o comportamento dos militares}

Com relaçáo ao comportamento dos comandantes das instituiçōes militares, os parlamentares usaram seus pronunciamentos para interpelar as Forças Armadas, convidando seus comandantes a colaborar com as investigaçôes feitas pela CNV:

As Forças Armadas podem dar uma importante contribuição ao Brasil, à reconstrução de sua tradição democrática, contribuindo com a consciência nacional, com a história brasileira, ajudando o Brasil a realizar a sua verdadeira conciliação nacional (senador Randolfe Rodrigues, PSOL-AP, 28 ago. 2013).

Às Forças Armadas, ao contrário de confrontação, este é um momento para darmos as mãos. Os caminhos da Comissão são os mesmos pelo qual deve trilhar o Exército brasileiro, porque é o caminho da ordem democrática (senador Randolfe Rodrigues, PSOL-AP, 10 dez. 2014).

Não cabe o silêncio das Forças Armadas; é necessário que haja o seu reconhecimento daquilo que foi identificado, com documentaçáo farta. Trata-se de gesto que abrirá caminho para a superação definitiva do passado, consolidando em base permanente o compromisso dos militares com o Estado democrático de direito (senador Eduardo Suplicy, PT-SP, 11 dez. 2014).

A recusa dos militares em fornecer dados e informaçóes de seus arquivos foi criticada por outros parlamentares e apontada como cumplicidade com as violaçóes aos direitos humanos. Para o deputado Chico Alencar (PSOL-RJ):

É inaceitável que os comandantes mostrem-se avessos e contrários às investigaçóes sobre a prática sistemática de tortura, execuçóes e outros 
crimes praticados pela ditadura de 1964-1985. Essa postura revela deplorável solidariedade com os crimes cometidos pelo Estado ou com sua aquiescência. Os militares, para cumprir seu papel institucional, não podem acobertar, sob o manto do corporativismo ou de pretensóes autoritárias, crimes cometidos por seus integrantes (11 dez. 2014).

A crítica do orador nos faz recordar que o segredo é uma das marcas da cultura militar, ao contrário da política, que exige transparência. O sigilo é usado para preservar assuntos cuja divulgação pode causar efeito negativo na imagem das instituiçóes militares. Tal cultura é apontada como um dos fatores que contribui para que a opinião pública tenha uma boa avaliação dos militares (Mathias e Andrade, 2012). Como argumentam Tavares (2005) e Figueiredo (2015), a cultura do segredo contribui para as políticas de memória voltadas para o esquecimento da perspectiva dos vencidos.

Outros parlamentares fizeram alusôes indiretas, embora críticas, ao comportamento dos militares em relação à $\mathrm{CNV}$ :

Os críticos à comissão enxergam em seus trabalhos, equivocadamente, revanchismo e vingança. A eles temos a dizer, simplesmente, que a verdade liberta e que reconciliação política só é digna desse nome quando fundada no máximo de conhecimento possível sobre a memória histórica (senador Lindbergh Farias, PT-RJ, 10 dez. 2014).

Aos que alegam que é preciso virar essa página da nossa história, a resposta é sim. Antes devemos completá-la, com a revelação de toda a verdade sobre as graves violaçóes de direitos humanos e sobre os crimes cometidos pelo regime militar, e processar, julgar e punir todos os responsáveis por eles, ainda impunes (deputada Luiza Erundina, PSB-SP, $1^{\circ}$ abr. 2014).

Apesar de reconhecerem o posicionamento dos comandantes das Forças Armadas, os parlamentares supracitados reivindicam uma mudança de postura das lideranças militares, especialmente do Exército, considerado o mais ativo durante o regime de exceção (D’Araujo, 2012). Assim, deputados e senadores de esquerda tentaram conquistar a adesão de tais lideranças na reformulação e revisão das políticas de memória. Certamente, trata-se de uma estratégia política que se limita ao plano da retórica, posto que é notória a posição antagônica dos representantes das Forças Armadas que, por sua vez, defendem uma política de esquecimento e a imposição de uma verdade sob a óptica dos vencedores (Bauer, 2015).

Também foram registrados pronunciamentos conciliadores ou que isentam os militares da atualidade das práticas do passado:

A atual geração das Forças Armadas brasileiras não tem responsabilidade com os crimes cometidos no passado (senador Randolfe Rodrigues, PSOLAP, 28 ago. 2013).

As Forças Armadas já superaram os traumas da história passada. Há uma ampla renovação, com jovens com outra mentalidade, mais democrática e pacífica (senador Eduardo Suplicy, PT-SP, 11 dez. 2014).

É interessante observar que a retórica conciliadora aparece apenas no Senado Federal, reforçando a polarizaçâo já apontada na Câmara dos Deputados e o clima político menos combativo entre os senadores, mesmo ao considerar os integrantes de esquerda, como os citados Randolfe Rodrigues e Eduardo Suplicy.

A conciliação constitui uma importante estratégia do discurso político em situações específicas, especialmente quando existe interesse em defender argumentos que unificam certas perspectivas políticas, mesmo que momentaneamente. Trata-se de um recurso utilizado para apagar contradiçóes e fazer aparentar uma pacificação ideológica (Fantinati, 1990). Desse modo, pode-se dizer que os oradores se mostraram compreensivos em relação à posição dos militares e acenaram para uma possível mediação de aproximação entre os defensores do trabalho da CNV e seus críticos.

Convém ressaltar que as Forças Armadas atuaram e ainda atuam como empreendedoras das políticas 
de esquecimento e como atores de veto de políticas de verdade. Desde 1979, "foi possível aos militares brasileiros atuarem como veto players sempre que entrou em debate a revisão da Lei de Anistia” (D'Araujo, 2012, p. 573). Esse poder de veto

explica-se pela existência de uma grande autonomia militar antes, durante e depois da ditadura, associada aos baixos níveis de respeito aos direitos humanos na sociedade brasileira e ao baixo interesse do Congresso e do governo em geral pelo tema das Forças Armadas (Idem, p. 573).

O estudo de Machado (2006) aponta que países que passaram pela experiência de regimes militares, como o Brasil, apresentam tendência maior a culto e respeito às Forças Armadas. Isso se explica pela cultura política subjacente a esses regimes, geralmente com medidas que apelam para o patriotismo, o respeito aos símbolos nacionais e a educação cívica instrumentalizada para a construção de representaçóes simbólicas positivas de personalidades que se destacaram na história nacional durante regimes conduzidos por ideologias militares. Afinal, a história oficial é uma versão da história dos vencedores, em que os feitos militares são exaltados e seus atores representados como heróis da pátria.

No caso brasileiro, a atuação dos militares é reconhecida até no processo de negociação da anistia política, cuja formatação contou com intensa atuação dos comandantes das Forças Armadas. Por essa razão, pode-se afirmar que a proposta de anistia aprovada e convertida em lei foi efetivamente controlada pelos militares, visando contemplar seus interesses e perspectivas (Machado, 2006; Soares, 2006). Assim, tanto a transição democrática como o processo de anistia herdaram os legados do autoritarismo, bem como a preservação da autonomia e do prestígio das Forças Armadas (Missiato, 2019; Costa e González, 2019).

De acordo com D’Araujo (2012, pp. 573, 575), a tradição de autonomia militar criou o pior cenário para a responsabilização individual dos crimes praticados nos governos de exceção e até mesmo nas questóes criminais sem cunho político. A autora ainda enfatiza:
[...] o poder das Forças Armadas no tema da anistia vai além das questóes de transição. Tem a ver com o tipo de relaçôes civil-militares gestadas no país desde a fundação da República, quando as Forças Armadas se transformam em ator político relevante. Desde então, com maior ou menor peso, os militares vêm tentando manter um padrão de autonomia quando se trata de definir seus interesses corporativos [...] Mesmo com a redemocratização, nenhum governo civil ousou encarar com determinação o tema da subordinação dos militares ao poder civil e democrático (D’Araujo, 2012, pp. 573, 586).

A atuação convergente das Forças Armadas com poder de veto nos leva a questioná-lo. A literatura nos mostra que "o prestígio e o poder de barganha de uma instituição são construídos e legitimados pelo tempo, mas especialmente pela relação estabelecida com a sociedade" (D’Araujo, 2012, p. 573). Assim, "as relaçóes civil-militares são uma rota de mão dupla. Não haverá autonomia ou prestígio militar, se a sociedade não o consentir” (Idem, p. 596). A autora complementa:

[...] o histórico protagonismo militar na política ficou no passado, mas algumas prerrogativas são social e legalmente consentidas. A reverência ou a cerimônia com que os governantes lidaram com os temas militares desde a redemocratização mostram esse legado histórico. Evidenciam também certa fragilidade democrática e, talvez, o trauma nacional em relação a intervenções armadas [...] Construímos e mantivemos relaçôes civil-militares duradouras em seus aspectos de autonomia e poder de barganha que combinam com baixa qualidade da democracia, com privilégios e com impunidade (D’Araujo, 2012, pp. 573, 596).

Outros autores argumentam que esse poder de veto é mantido e fortalecido em função de um conjunto de fatores, como "a impunidade dos crimes praticados em nome do regime autoritário" (Gallo, 2016, p. 340), a falta de revisão da Lei da Anistia, a manutenção de um sistema de formação nas academias militares que não prima por valores democráticos e 
respeito aos direitos humanos, a existência de sistemas estadual e federal de justiça militar e a manutenção do sigilo sobre arquivos da repressão. Por essas razóes, os militares interpretaram a proposta de criação da CNV como "revanchismo". Na visão do Clube Militar, os comissionários cometeram crime de "injúria” e "difamação" contra os militares listados no relatório (Idem, p. 339).

A falta de responsabilização pelos crimes de tortura constitui "a expressão mais concreta da persistência da impunidade e, mais grave ainda, de democracia incompleta" (Padrós, 2012, p. 68), "ancorada no regime de uma política de esquecimento" (Quinalha, 2013, p. 182). Como salienta Mezarobba, "os militares permanecem unidos e não expressam arrependimento" (2006, p. 162). Silva Filho complementa que

nenhum militar brasileiro adotou um gesto semelhante ao comandante do Exército argentino que em 1995 pediu desculpas à nação pelos erros cometidos pela ditadura civil-militar daquele país (2010, p. 11).

A oposição dos comandantes das Forças Armadas, especialmente do Exército, pode ser entendida como estratégia para manter uma política de memória que, desde a Lei da Anistia, favorecia a confortável posição estabelecida pelas ambiguidades inerentes à ideologia de reconciliação que pautou a política de anistia geral, ampla e irrestrita. Tal política é entendida como confortável para os militares, porque, ao favorecer a imagem pública das Forças Armadas, levou outras memórias, consideradas incômodas, ao esquecimento. São as memórias de vítimas, mortos e desaparecidos que ainda não obtiveram seu reconhecimento como vítimas de tortura e de violência política dos agentes do Estado (Abrão e Genro, 2012; Safatle, 2014; Fico, 2017).

Nesse item do debate parlamentar há um tópico que foi silenciado e que convém ser registrado. Trata-se do que a literatura trata como esquerda militar, ou seja, os militares que foram perseguidos e se tornaram vítimas do próprio regime porque discordavam das práticas de tortura e das demais formas de violência política (Alves, 2005; Machado, 2011; Cunha, 2014). O tema fez parte de um dos grupos de trabalho da CNV, mas não obteve repercussão pública.
O silenciamento ocorreu dos dois lados, isto é, nem os militares e seus representantes de direita, nem os parlamentares de esquerda incluíram o assunto na discussão. Esse grupo, portanto, foi condenado ao esquecimento por todos os atores do debate no Congresso Nacional.

\section{Debate sobre a composiçáo da $\mathrm{CNV}^{8}$}

Apesar de ter sido um dos aspectos expressivos do debate, a composição da CNV não foi contestada nem criticada, mas sim elogiada por parlamentares:

Os sete brasileiros(as) que estáo compondo a Comissão Nacional da Verdade são dignos cidadãos e cidadãs de reconhecido valor político, pessoal e com uma história de participação efetiva na luta de resistência à ditadura militar e de redemocratização do País (deputada Luiza Erundina, PSB-SP, 17 maio 2012).

Os nomes são notáveis. Fiquei orgulhoso de ver hoje, na instalação da comissão, os membros empossados, sem dúvida nenhuma, todos eles honrando e dignificando sua indicação, com plenas condiçôes de realizar um bom trabalho (senador de Romero Jucá, PMDB-RR, 16 maio 2012).

Os sete integrantes da CNV são nomes de notória reputação e respeitabilidade jurídica, profissional e política, e nos dão a garantia de que os trabalhos dessa comissão serão realizados com rigor (senadora Lídice da Mata, PSB-BA, 16 maio 2012).

Como se vê, nos trechos destacados, os elogios ressaltam a dignidade pessoal de cada integrante $\mathrm{da}$ $\mathrm{CNV}$, a trajetória de cada um e o envolvimento na defesa dos direitos humanos, no combate ao regime militar e na luta pela redemocratização. $\mathrm{O}$ capital de reputação dos sete integrantes da $\mathrm{CNV}$ foi apontado como garantia de um trabalho de qualidade e compromisso com a apuração da verdade e o resgate da memória política do país. 
A composição da CNV agradou a todos os seus defensores, porém silenciou seus opositores, uma vez que nenhum dos parlamentares críticos da $\mathrm{CNV}$ mencionou seus integrantes. Os críticos focaram seus argumentos genericamente na comissão, mas sem mencionar individualmente seus integrantes. Certamente isso se deve a uma provável estratégia dos oradores para evitar processos por injúria e difamação. Afinal, ao criticar a comissão, os argumentos se dirigem praticamente a quem os nomeou, ou seja, o Estado, sem interferência na reputação individual de seus componentes.

Em suma, a CNV foi tratada pelos parlamentares como um corpo burocrático. Trata-se de em uma abordagem que se coaduna com a visão de Bourdieu de que uma comissão oficial é formada por "um conjunto de pessoas investidas de uma missão de interesse geral e conclamadas a transcender seus interesses particulares para produzir propostas universais" (2011, p. 123). A CNV aparece, portanto, no debate parlamentar como um corpo burocrático que se apresenta como um grupo universal, isto é, "um órgão de reflexão e um instrumento racional encarregado de realizar o interesse geral" (Idem, p. 112). Isso porque os atos burocráticos pertencem à categoria de atos oficiais, aqueles "realizados em situação de autoridade, por pessoas autorizadas" (Idem, p. 112).

\section{Consideraçóes finais}

O objetivo deste artigo foi analisar as lutas discursivas encetadas no debate parlamentar acerca da Comissão Nacional da Verdade (CNV) no Congresso Nacional brasileiro, desde a apresentação do projeto de criação, em 2011, até a finalização de suas atividades, em 2014. A maioria dos 512 pronunciamentos do corpus analisado pertence a integrantes da Câmara dos Deputados, que conta com um número maior de parlamentares. ${ }^{9} \mathrm{O}$ perfil dos deputados e senadores que fizeram pronunciamentos a favor da CNV é majoritariamente de partidos de esquerda, como PT, PSOL, PSB e PCdoB. Os pronunciamentos desse conjunto de parlamentares podem ser enquadrados em uma perspectiva específica de justiça, que combina anistia, busca da verdade e resgate da memória das vítimas, em um esforço para reconstruir a história dos vencidos. No caso em estudo, contudo, a ênfase ficou no resgate da memória das vítimas.

Nossa análise mostrou um alinhamento retórico majoritário com a defesa da instalação da CNV, sua composição e a apresentação de seu relatório final. $\mathrm{O}$ esforço argumentativo dos parlamentares que apoiavam o governo do PT à época dos debates convergiu para a legitimação dos trabalhos da comissão, com ênfase para os aspectos positivos da iniciativa e baixa expressão crítica ao resultado final do trabalho. Dessa forma, podemos inferir que a interpretação desses parlamentares converge para a análise de Oliveira, que entende a instalação da CNV como uma "vitória simbólica dos vencidos" (2011, p. 17). Entretanto, é oportuno ressaltar que a dimensão simbólica foi supervalorizada pelos oradores dos partidos de esquerda mencionados, talvez como estratégia discursiva para superestimar os resultados da $\mathrm{CNV}$ e reduzir o impacto crítico em relação às limitaçóes. Isso porque eventuais críticas atingiriam também o governo federal, visto se tratar de uma iniciativa do PT.

A direita, por sua vez, praticamente silenciou, mesmo sendo contrária ao trabalho da CNV. Apenas dois parlamentares criticaram abertamente a comissão - Jair Bolsonaro e Arolde de Oliveira -, os quais foram integrantes dos quadros do Exército brasileiro. Essa condição certamente motivou suas manifestaçóes, posto que ambos atuaram no debate parlamentar como porta-vozes das Forças Armadas, defendendo suas práticas e não admitindo que houve excessos ou erros durante o regime de exceção. Essa foi a mesma postura dos comandantes das três forças: Exército, Marinha e Aeronáutica.

Cabe questionar o que levou a direita a optar pelo silenciamento. Temos duas possíveis hipóteses explicativas para tal fato. A primeira decorre do receio dos parlamentares de que seriam malvistos pela opinião pública, diante da ampla adesão dos meios de comunicaçáo à ideia de que seria realmente necessário investigar e punir os crimes cometidos pela ditadura. A segunda hipótese é que, diante dos resultados, que se limitaram a buscar a verdade sob a óptica das vítimas, os parlamentares representantes da direita perceberam que não havia necessidade de insistir no debate sobre o tema, visto que a batalha de 
memória já havia sido conquistada antecipadamente, quando as forças conservadoras agiram para restringir o escopo de atuação da CNV ao direito à verdade e à memória, sem a possibilidade de fazer justiça.

Nesse sentido, o relatório final da CNV enquadra-se no rol das políticas de memória classificadas como promotoras do esquecimento, cujo propósito é preservar a imagem e o prestígio dos militares (D’Araujo, 2012; Machado, 2006; Figueiredo, 2015). Concluímos, portanto, que esse trabalho de memória não deve ser desprezado ou diminuído. Afinal, como vimos na primeira parte do texto, as comissóes da verdade em outros países tiveram tal vertente como um de seus pilares (Aydos e Figueiredo, 2013; Indursky e Mayorca, 2019). Destacamos aqui a perspectiva do resgate da memória das vítimas como um dos processos relevantes no caso brasileiro. Sem dúvida, esses processos contribuíram para reabilitar a importância das vítimas como sujeitos políticos, ao permitir a reconstituição de suas memórias e seu sofrimento moral. Argumentamos que a centralidade da perspectiva das vítimas da ditadura contribui para reparar a injustificável marginalização política que até então havia predominado.

Apesar disso, defendemos o ponto de vista, com base na análise apresentada, de que a maioria dos parlamentares alinhados ao governo do PT, os quais defenderam a instalação, a composição e os resultados da CNV, contentou-se com o fato de que a comissão contemplou a política de memória nos termos já descritos. A nosso ver, entretanto, o trabalho de resgate histórico e reabilitação das vítimas realizado pela $\mathrm{CNV}$, apesar de relevante e necessário, não foi suficiente, pois faltou a dimensão da justiça de transição, nos termos em que abordamos na primeira seção do texto (Fernandes, 2015; Hollanda, 2018; Abrão e Torelly, 2012).

É oportuno enfatizar que, com relação à dimensão da justiça de transição, o relatório final da CNV seguiu o padrão da chamada transição incompleta ou conservadora, que avança no resgate da memória das vítimas, mas não consegue efetivar plenamente a justiça, visto que a anistia a torturadores e criminosos é mantida (Safatle e Teles, 2010; Abrão e Genro, 2012). Assim, concluímos que a relação entre as políticas de memória e a justiça de transição, complementares segunda a literatura, ficou prejudicada. Acreditamos que isso se deve a três fatores que se complementam. O primeiro está no peso que a política de anistia adquiriu no Brasil, o que significou, na prática, adesão à perspectiva do tempo dos vencedores e uma política de memória voltada para o esquecimento das atrocidades cometidas pelos agentes do Estado durante a ditadura (Bauer, 2015). O segundo fator refere-se ao poder que as Forças Armadas exercem no âmbito político e o culto a essas instituiçóes pela sociedade, conforme tratado anteriormente (D'Araujo, 2012; Machado, 2006). O terceiro diz respeito ao recuo do governo federal, à época comandado pelo $\mathrm{PT}$, no processo de instalação da $\mathrm{CNV}$, ao ceder a pressóes de forças conservadoras e aceitar a exclusão do item que propunha direito das vítimas à justiça, priorizando apenas o direito à verdade. Isso explica também por que os parlamentares de esquerda enfatizaram tanto a dimensão do direito à verdade, sem criticar a incompletude da iniciativa.

Nessa ordem de ideias, observamos que, apesar dos avanços apontados, a CNV acabou sendo instrumentalizada em prol dos projetos que buscam uma política de memória voltada para o esquecimento do passado, priorizando a perspectiva histórica dos vencedores e negligenciando a história dos vencidos (Safatle e Teles, 2010). Dessa forma, a comissão alinhou-se à visão estabelecida pela anistia, com nítido favorecimento dos agentes de repressão. Trata-se, portanto, da continuidade da política de eliminaçáo simbólica da história (Safatle, 2014) e dos projetos de instrumentalização autoritária da memória (Guimarães e Starling, 2012; Abrão e Genro, 2012), conforme expusemos na parte inicial do texto.

Nesse sentido, considerando o caso analisado em uma perspectiva teórica mais ampla, percebemos que permanecem presentes e atuais as tensóes apontadas anteriormente na literatura sobre história e memória (Nora, 1993; Halbwachs, 2004a; 2004b; Ricoeur, 2007; Le Goff, 2013); memória, esquecimento e silêncio (Ferreira, 2011; Lira, 2009); tempo dos vencidos e tempo dos vencedores (Bauer, 2015). Tal constataçâo nos leva a concluir que as batalhas de memória sobre os mortos e desaparecidos durante a ditadura continuarão como parte da dinâmica do trabalho de memória, ou seja, algo inerente ao processo 
de (re)construção da memória política nacional. É a lógica dos "passados presentes", "passados eternos", "passados que não passam”, "passados estendidos" (Bauer, 2015).

Como vimos, apesar das distinçóes entre as abordagens teóricas, apresentamos o argumento de que memória e história também podem ser complementares; tal premissa foi reforçada após a análise dos pronunciamentos parlamentares sobre a CNV. Essa complementação se dá porque o trabalho de memória realizado pela comissão contribuirá para possíveis revisóes da história política brasileira. Afinal, a história não deve ser compreendida como algo fixo e imutável. Nesses termos, é importante salientar que toda a documentação produzida ao longo do trabalho de reconstituição das memórias das vítimas servirá de fonte documental para estudiosos interessados em aprofundar suas pesquisas históricas sobre o assunto.

O debate parlamentar sobre esse tema certamente terá desdobramentos futuros, posto que o trabalho da CNV ficou incompleto. Isso certamente será objeto de novas lutas discursivas no Congresso Nacional, seguindo a lógica da verdade hermenêutica, nos termos de Arendt (2000) e Giddens (1995), conforme apresentamos no início deste texto. As mudanças recentes no Poder Executivo e no próprio Congresso Nacional também contribuirão para novas disputas de sentidos e para a busca de outros regimes de verdade nessa contínua batalha de memórias, em que os passados continuarão a ser revisitados e reinterpretados, visando uma justiça de transição de maior expressão. Afinal, como vimos, tal modalidade de justiça constitui algo em processo e que se efetiva em várias etapas (Abrão e Torelly, 2012; Teles, 2018).

\section{Notas}

1 Todas as citaçóes de textos em outros idiomas foram traduzidas para o português pelo autor.

2 O projeto de lei recebeu 23 emendas, a maioria relativa a procedimentos e metodologia de trabalho. Apenas duas foram aprovadas. A primeira, de autoria do deputado Duarte Nogueira (PSDB-SP) permitia que qualquer cidadão prestasse informaçôes à CNV, desde que houvesse comprovaçáo. A segunda, assinada por Antonio Carlos Magalháes Neto (DEM-BA), estabelecia limites para o perfil dos integrantes da comissão, como: não exercer cargos na executiva dos partidos políticos nem ocupar cargos comissionados em instituiçóes públicas federais. Para a íntegra das emendas ao projeto, acessar: https://www.camara.leg.br/proposicoesWeb/prop_ emendas;jessionid=DA752D4A2804304F88FC93EF45207C93. proposicoesWeb2?idProposicao $=478193 \&$ subst $=0$, consultado em 27/12/2019.

3 A seçâo "Comissōes da verdade versus políticas de reconciliação e anistia política" apresenta uma contextualização dos planos nacionais de direitos humanos.

4 Guilherme Gomes Lund (1947-?), filho de Júlia Gomes Lund e João Carlos Lund, foi um estudante de arquitetura, militante do Partido Comunista do Brasil. Ele desapareceu em dezembro de 1973.

5 A expressão "justiça em tempos de transiçáo" foi utilizada pela primeira vez em 1992 pela jurista argentina Ruti G. Teitel, e sua consagração ocorreu com a publicação da obra Transitional justice genealogy. A expressão abrange a articulação entre direito e política em democracias ainda em processo de estabilizaçáo institucional (Teitel, 2003; Kritz, 2004; Hollanda, 2018).

6 Para ler o texto da lei n. 6 683, de 28 de agosto de 1979, acessar: http://www.planalto.gov.br/ccivil_03/ leis/L6683.htm, consultado em 27/12/2019.

7 Todos os pronunciamentos, debates, discussóes, entre outros textos citados e pesquisados podem ser encontrados, no caso dos deputados, em: https://www2.camara.leg. br/atividade-legislativa/discursos-e-notas-taquigraficas; e no caso dos senadores, em: https://www25.senado. leg.br/web/atividade/pronunciamentos, consultados em 6/1/2020.

8 A comissão foi formada por: Claudio Fonteles, Gilson Dipp, José Carlos Dias, José Paulo Cavalcanti Filho, Maria Rita Kehl, Paulo Sérgio Pinheiro, Pedro Dallari e Rosa Maria Cardoso da Cunha.

9 Na Câmara há 513 deputados; o Senado é formado por 81 parlamentares.

$10 \mathrm{O}$ total se refere ao número de parlamentares e não de pronunciamentos.

\section{BIBLIOGRAFIA}

ABRÃO, Paulo \& GENRO, Tarso Fernando. (2012), Os direitos da transição e a democracia no Brasil: estudo sobre justiça de transição e teoria da democracia. Belo Horizonte, Fórum.

ABRÃO, Paulo \& TORELLY, Marcelo D. (2012), "Mutaçôes do conceito de anistia na justiça de transição brasileira”. Revista de Direito Brasileira, 3 (2): 357-379. 
ABRÃO, Paulo. (2012), "A lei de anistia no Brasil: as alternativas para a verdade e a justiça". Acervo, 24 (1): 119-138.

ADORNO, Sérgio. (2010), "História e desventura: o 3 o programa nacional de direitos humanos. Novos estudos - CEBRAP, (86): 5-20.

ALVES, Maria Helena Moreira. (2005), Estado e oposição no Brasil: 1964-1984. Bauru, Edusc.

ARAÚJO, Maria Paula Nascimento \& SANTOS, Myrian Sepúlveda dos. (2007), "História, memória e esquecimento: implicações políticas". Revista Crítica de Ciências Sociais, (79): 95-111.

ARENDT, Hannah. (2000), Entre o passado e o futuro. São Paulo, Perspectiva.

ARNOLD, R. Douglas. (1990), The logic of congressional action. New Haven, Yale University Press.

ARTHUR, Paige. (2011), “Como as 'transições' reconfiguraram os direitos humanos: uma história contextual da justiça de transição" in F. Reátegui (org.), Justiça de transiçâo: manual para a América Latina, Brasília/Nova York, Comissão de Anistia, Ministério da Justiça/Centro Internacional para a Justiça de Transição (ICTJ), pp. 73-134.

AYDOS, Valéria \& FIGUEIREDO, César Alessandro S. (2013), "A construção social das vítimas da ditadura militar e a sua ressignificação política”. Interseçôes, 15 (2): 392-416.

BAUER, Caroline Silveira. (2015), "O debate legislativo sobre a criação da Comissão Nacional da Verdade e as múltiplas articulaçôes e dimensōes de temporalidade da ditadura civil-militar brasileira”. Anos 90, 22 (42): 115-152.

BOURDIEU, Pierre. (2011), "Espíritos de Estado: gênese e estrutura do campo burocrático" in $\mathrm{P}$. Bourdieu, Razóes práticas: sobre a teoria da ação, Campinas, Papirus, pp. 121-142.

CANABARRO, Ivo Santos. (2014), "Caminhos da Comissão Nacional da Verdade (CNV): memórias em construção". Sequência, 35 (69): 215-234.

CARDOSO, Irene de Arruda Ribeiro. (2001), Para uma crítica do presente. São Paulo, Editora 34.

CHARAUDEAU, Patrick. (2017), Discurso politico. São Paulo, Contexto.

COIMBRA, Cecília Maria Bouças. (2013), "Comissão Nacional da Verdade: acordos, limites e enfrentamentos" in A. M. C. Ximenes, C. dos Reis \& R. W de Oliveira (orgs.), Entre garantia de direitos e práticas libertárias, Porto Alegre, Conselho Regional de Psicologia do Rio Grande do Sul, pp. 35-42.

COSTA, Maíra Pereira da \& GONZÁLEZ, Rodrigo Stumpf. (2019), "Justiça de transição, cultura política e legado autoritário no Cone Sul”. Revista Sul-Americana de Ciência Política, 5 (1): 125-146.

CUEVA, Eduardo González. (2011), "Até onde vão as comissóes da verdade?” in F. Reátegui (org.), Justiça de transição: manual para a América Latina, Brasília/Nova York, Comissão de Anistia, Ministério da Justiça/International Center for Transitional Justice (ICTJ), pp. 339-356.

CUNHA, Paulo Ribeiro Rodrigues da. (2014), “A Comissão Nacional da Verdade e os militares perseguidos: desafios de um passado no tempo presente e futuro". Acervo, 27 (1): 137-155.

D’ALÉSSIO, Márcia Mansor. (1992), "Memória: leituras de M. Halbwachs e P. Nora”. Revista Brasileira de História, 13 (25-26): 97-103.

D’ARAUJO, Maria Celina. (2012), “O estável poder de veto Forças Armadas sobre o tema da anistia política no Brasil". Varia Historia, 28 (48): 573-597.

ELIAS, Norbert. (1989), Sobre el tiempo. Cidade do México, Fondo de Cultura Econômica.

FANTINATI, Carlos Erivany. (1990), “Sobre o discurso político". Alfa, 34: 1-10.

FERNANDES, Pádua. (2015), "Justiça de transição e o fundamento nos direitos humanos: perplexidades do relatório da Comissão Nacional da Verdade brasileira" in O. Akamine Jr., C. Kashiura Jr. \& T. Melo (orgs.), Para a crítica do direito: reflexóes sobre teorias e práticas jurídicas, São Paulo, Outras Expressóes, pp. 717-745.

FERREIRA, Maria Leticia Mazzucchi. (2011), "Políticas da memória e políticas do esquecimento". Aurora, (10): 102-118.

FICO, Carlos. (2017), "Ditadura militar brasileira: aproximaçōes teóricas e historiográficas”. Tempo e Argumento, 9 (20): 5-74. 
FIGUEIREDO, Lucas. (2015), Lugar nenhum: militares e civis na ocultação dos documentos da ditadura. São Paulo, Companhia das Letras.

GALLO, Carlos Artur. (2016), "A Comissão Nacional da Verdade e a reconstituição do passado recente brasileiro: uma análise preliminar da sua atuação". Revista Estudos de Sociologia, 20 (39): 327-345.

GASPAROTTO, Alessandra \& PADRÓS, Enrique Serra. (2010), "A ditadura civil-militar em sala de aula: desafios e compromissos com o resgate da história recente e da memória” in V. L. Barroso, N. M. Pereira, M. A. Bergamaschi, S. Gedoz \& E. S. Padrós (orgs.), Ensino de história: desafios contemporâneos, Porto Alegre, EST, pp. 55-72.

GASPAROTTO, Alessandra; DELLA VECHIA, Renato; AMARO, Silveira da \& BRANSÃO, Marília. (2012), "A criação da Comissão Nacional da Verdade e a luta por verdade, memória e justiça no Brasil”. Espaço Plural, 13 (27): 84-95.

GIDDENS, Anthony. (1995), "A vida em uma sociedade pós-tradicional” in U. Beck, A. Giddens \& S. Lash, Modernização reflexiva: política, tradição e estética na ordem social moderna. São Paulo, Unesp, pp. 73-133.

GONZÁLEZ, Eduardo. (2012), Observaçōes sobre o Mandato Legal da Comissão Nacional da Verdade do Brasil. Nova York, International Center for Transitional Justice.

GUILHOT, Nicolas. (2005), The democracy makers: human rights and international order. Nova York, Columbia University Press.

GUIMARĀES, Juarez \& STARLING, Heloísa. (2012), Dimensóes politicas da justiça. Rio de Janeiro, Record.

HALBWACHS, Maurice. (2004a), Los marcos sociales de la memoria. Barcelona, Anthropos Editorial.

HALBWACHS, Maurice. (2004b), La memoria colectiva. Zaragoza, Prensas Universitarias de Zaragoza.

HARTOG, François. (2013), "Experiências do tempo: da história universal à história global?”. História, Histórias, 1 (1): 164-179.

HEURTIN, Jean-Philippe. (1999), L'espace public parlementaire: Essai sur les raisons du législateur. Paris, Presses Universitaires de France.
HOLLANDA, Cristina Buarque de. (2018), "Direitos humanos e democracia: a experiência das comissóes nacional e estaduais da verdade no Brasil". Revista Brasileira de Ciências Sociais, 33 (96): e339610.

INDURSKY, Alexei Conte \& MAYORCA, Daniela Sevegnani. (2019), "Clínicas do Testemunho: a política de reparação psíquica no Brasil”. Revista Sul-Americana de Ciência Política, 5 (1): 163-178.

KOERNER, Andrei. (2003), "O papel dos direitos humanos na política democrática: uma análise preliminar". Revista Brasileira de Ciências Sociais, 18 (53): 143-181.

KRITZ, Neil J. (2004), Transitional justice: how emerging democracies reckon with former regimes. Washington, United States Institute of Peace Press.

LAFER, Celso. (2012), "Consideraçóes sobre a Comissão Nacional da Verdade”. Migalhas, 22 maio. Disponível em http://www.migalhas.com. br/dePeso/16,MI155965,31047-Consideraco es+Sobre $+\mathrm{a}+$ Comissao+Nacional $+\mathrm{da}+$ Verdade, consultado em 20/12/2019.

LANDOWSKI, Éric. (1977), "Le débat parlementaire et l'écriture de la loi”. Revue Française de Science Politique, 27 (3): 428-441.

LE GOFF, Jacques. (2013), História e memória. Campinas, Editora Unicamp.

LIRA, Elizabeth. (2009), "Las resistencias de la memoria: olvidos jurídicos y memorias sociales" in R. Vinyes (ed.), El Estado y la memoria: gobiernos y ciudadanos frente a los traumas de la historia. Barcelona, RBA, pp. 67-116.

MACHADO, Flávia Burlamaqui. (2006), As Forças Armadas e o processo de anistia no Brasil (19792002). Dissertação de mestrado. Universidade Federal do Rio de Janeiro, Rio de Janeiro.

MACHADO, Flávia Burlamaqui. (2011), “As Forças Armadas, a anistia de 1979 e os militares cassados". Militares e Política, (6): 114-140.

MATHIAS, Suzeley Kalil \& ANDRADE, Fabiana de Oliveira. (2012), "O Serviço de Informaçóes e a cultura do segredo". Varia Historia, 28 (48): 537-554. 
MEISTER, Robert. (2012), After evil: a politics of human rights. Nova York, Columbia University Press.</bok $>$ ]

MEZAROBBA, Glenda. (2006), Um acerto de contas com o futuro: a anistia e suas consequências - um estudo do caso brasileiro. São Paulo, Associação Editorial Humanitas/Fapesp.

MIGUEL, Luis Felipe \& FEITOSA, Fernanda. (2009), "O gênero do discurso parlamentar: mulheres e homens na tribuna da Câmara dos Deputados". Dados, 52 (1): 201-221.

MISSIATO, Victor Augusto Ramos. (2019), "Forças Armadas, autonomias e autoritarismo: a atuação das Forças Armadas de Brasil e Chile nas transiçôes rumo à democracia”. Revista Sul-Americana de Ciência Política, 5 (1): 1-19.

MOREIRA, Davi Cordeiro. (2016), Com a palavra os nobres deputados: frequência e ênfase temática dos discursos dos parlamentares brasileiros. Tese de doutorado. Universidade de São Paulo, São Paulo.

MOTTA, Rodrigo Patto Sá. (2018), "Cultura política e ditadura: um debate teórico e historiográfico". Tempo e Argumento, 10 (23): 109-137.

NEVES, Raphael. (2012), "Uma comissão da verdade no Brasil? Desafios e perspectivas para integrar direitos humanos e democracia". Lua Nova, (86): 155-186.

NORA, Pierre. (1993), "Entre a memória e a história: os lugares de memória”. Projeto História, 10: 7-28.

OLIVEIRA, Gabriela Goergen. (2013), Comissão Nacional da Verdade: a busca pela concretização da justiça de transição no Brasil. Monografia de conclusão de curso. Pontifícia Universidade Católica do Rio Grande do Sul, Porto Alegre.

OLIVEIRA, Luciano. (2011), "Ditadura militar, tortura e história: a 'vitória simbólica' dos vencidos”. Revista Brasileira de Ciências Sociais, 26 (75): 7-25.

PADRÓS, Enrique Serra. (2012), "Ditadura brasileira: verdade, memória... e justiça?” Historiae, 3 (3): 65-84.

PAIVA, Claudia Gomes. (2006), Uma viagem pelo discurso parlamentar: gênero discursivo por desvendar. Dissertação de mestrado. Universidade de Brasília, Brasília.
PEREIRA, Mateus Henrique de Faria. (2015), "Nova direita? Guerras de memória em tempos de Comissão da Verdade (2012-2014)". Varia Historia, 31 (57): 863-902.

PINTO, Simone Rodrigues. (2010), “Direito à memória e à verdade: comissóes de verdade na América Latina”. Revista Debates, 4 (1): 128-143.

QUINALHA, Renan Honório. (2013), “Com quantos lados se faz uma verdade? Notas sobre a Comissão Nacional da Verdade e a 'teoria dos dois demônios"'. Revista Jurídica da Presidência, 15 (105): 181-204.

RAMÍREZ, Oriana Bernasconi; SANTELICES, Daniela Mansilla \& SUÁREZ MADARIAGA, Rodrigo (2019), "Las comisiones de la verdad en la batalla de la memoria: usos y efectos disputados de la verdad extrajudicial en Chile". Colombia Internacional, (97): 27-55.

REIS, Daniel Aarão. (2010), "Ditadura, anistia e reconciliação”. Estudos Históricos, 23 (45): 171-186.

REIS, Daniel Aarão. (2018), "A Constituição cidadã e os legados da ditadura". Locus, 24 (2): 277-297.

REIS, Daniel Aarão; RIDENTI, Marcelo \& MOTTA, Rodrigo Patto Sá (orgs.). (2014), A ditadura que mudou o Brasil: 50 anos do golpe de 1964. Rio de Janeiro, Zahar.

RICOEUR, Paul. (2007), A memória, a história, o esquecimento. Campinas, Editora Unicamp.

RODRÍGUEZ, Catalina Fuentes. (2010), "La aserción parlamentaria: de la modalidad al metadiscurso". Oralia, 13: 97-125.

RODRÍGUEZ, Catalina Fuentes. (2012), "La verdad como estrategia de legitimación discursiva”. Discurso \& Sociedad, 6 (1): 128-155.

ROMANELLI, San. (2015), "Comissão Nacional da Verdade - modo de usar: abecedário das reparaçôes”. Revista Insight Inteligência, 69: 114-127.

ROMERO, Gabriel Ruiz \& HRISTOVA, Marije. (2019), "Comisionar la verdad y la memoria en la sociedad”. Colombia Internacional, 97 (1): 3-26.

SAFATLE, Vladimir \& TELES, Edson. (2010), "Apresentação" in V. Safatle \& E. Teles (orgs.), O que resta da ditadura: a exceção brasileira, São Paulo, Boitempo, pp. 9-12. 
SAFATLE, Vladimir. (2014), "A anistia de 1979 e seus significados, ontem e hoje" in D. A. Reis, M. Ridenti \& R. P. S. Motta (orgs.), A ditadura que mudou o Brasil: 50 anos do golpe de 1964, Rio de Janeiro, Zahar, pp. 172-185.

SCHMIDT, Benito Bisso. (2007), "Cicatriz aberta ou página virada? Lembrar e esquecer o golpe de 1964 quarenta anos depois". Anos 90, 14 (26): 127-156.

SEIXAS, Ivan Akselrud \& SOUZA, Silvana Aparecida de. (2015), "Comissão Nacional da Verdade e a rede de comissóes estaduais, municipais e setoriais: a trajetória do Brasil”. Estudos de Sociologia, 20 (39): 347-364.

SETTON, Maria da Graça Jacintho. (2013), "Marcel Mauss e Norbert Elias: notas para uma aproximação epistemológica”. Educaçâo \& Sociedade, 34 (122): 195-210.

SILVA FILHO, José Carlos Moreira da. (2010), "Dever de memória e a construção da história viva: a atuação da Comissão de Anistia do Brasil na concretização do direito à memória e à verdade” in B. de S. Santos, P. Abrão, C. M. dos Santos \& M. D. Torelly (orgs.), Repressão e Memória Politica no Contexto Ibero-Brasileiro: estudos sobre Brasil, Guatemala, Moçambique, Peru e Portugal, Brasília/Coimbra, Ministério da Justiça/Universidade de Coimbra, pp. 186-227.

SOARES, Inês Virgínia Prado \& BASTOS, Lucia Helena Arantes Ferreira. (2011), “A verdade ilumina o direito ao desenvolvimento? Uma análise da potencialidade dos trabalhos da Comissão Nacional da Verdade no cenário brasileiro". Revista Anistia, (6): 44-69.

SOARES, Inês Virgínia Prado \& QUINALHA, Renan Honório. (2011), "Lugares de memória no cenário brasileiro da justiça de transição”. Revista Internacional de Direito e Cidadania, 10: 75-86.

SOARES, Samuel Alves. (2006), Controles e autonomia: as Forças Armadas e o sistema politico brasileiro (1974-1999). São Paulo, Editora Unesp.
TAVARES, Flávio. (2005), Memórias do esquecimento: os segredos dos poróes da ditadura. Rio de Janeiro, Record.

TEITEL, Ruti G. (2003), “Transitional justice genealogy”. Harvard Human Rights Journal, (16): 69-94.

TELES, Edson Luis de Almeida. (2010), “A tensão entre governo e movimentos sociais na luta pela verdade”. Margem Esquerda, (19): 29-34.

TELES, Edson Luis de Almeida. (2012), "Direitos humanos, governança e democracia”. Ideias, 3 (1): 55-71.

TELES, Edson Luis de Almeida. (2018), O abismo da história: ensaios sobre o Brasil em tempos de Comissão da Verdade. São Paulo, Alameda.

VINYES, Ricard (ed.). (2009), El Estado y la memoria: gobiernos y ciudadanos frente a los traumas de la historia. Barcelona, RBA.

WAEVER, Ole. (2002), "Identity, communities and foreign policy: discourse analysis as foreign policy theory" in L. Hansen \& O. Waever (eds.), European Integration and National Identity: the challenge of the Nordic states, Londres, Routledge, pp. 20-49.

WEICHERT, Marlon Alberto. (2013), "A Comissão Nacional da Verdade" in J. C. M. da Silva Filho, P. Abrão \& M. D. Torelly (orgs.), Justiça de transiçâo nas Américas: olhares interdisciplinares, fundamentos epadróes de efetivação, Belo Horizonte, Fórum, p. 161-174.

WEICHERT, Marlon Alberto. (2014), "O relatório da Comissão Nacional da Verdade: conquistas e desafios". Projeto História, 50: 86-137.

WINAND, Érica Cristina Alexandre \& BIGATÃO, Juliana de Paula. (2014), "A política brasileira para os direitos humanos e sua inserção nos jornais: a criação da Comissão Nacional da Verdade”. Revista Interdisciplinar de Direitos Humanos, 2 (1): 41-62. 


\section{O DEBATE PARLAMENTAR SOBRE A COMISSÁO NACIONAL DA VERDADE NO CONGRESSO NACIONAL BRASILEIRO}

\section{Antonio Teixeira de Barros}

Palavras-chave: Comissão Nacional da Verdade; Memória política; Direitos humanos; Congresso Nacional; Discursos parlamentares.

Este artigo analisa o debate parlamentar no Congresso Nacional brasileiro sobre a Comissão Nacional da Verdade (CNV), desde a apresentação do projeto de sua criação, em 2011, até a finalização de suas atividades, em 2014. O corpus é formado por 512 pronunciamentos, sendo que 416 são de deputados e 96, de senadores. O referencial teórico é focado em estudos de políticas da memória e justiça de transição. No debate prevaleceu a voz dos partidos de esquerda, favorável à CNV, enquanto a direita usou a estratégia do silêncio. Apenas dois parlamentares vinculados ao Exército se manifestaram contra a CNV. Apesar de reconhecerem a importância do relatório final da comissão, a maioria dos parlamentares (da esquerda) considerou o trabalho insuficiente porque a comissão se pautou na busca da verdade e da memória, mas náo pôde fazer justiça, punindo os torturadores.

\section{THE PARLIAMENTARY DEBATE ON THE NATIONAL TRUTH COMMISSION IN THE BRAZILIAN NATIONAL CONGRESS}

\section{Antonio Teixeira de Barros}

Keywords: National Truth Commission; Political memory; Human rights; Brazilian National Congress; Parliamentary speeches.

This article analyzes the parliamentary debate held at the Brazilian National Congress on the National Commission of Truth (CNV), from the presentation of the project of its creation, in 2011, until the conclusion of its activities, in 2014. The corpus consists of 512 pronouncements, of which 416 were presented by deputies and 96 by senators. The theoretical framework focuses on studies of memory policies and transitional justice. In the debate, the voice of the left parties, favorable to the CNV, prevailed, while the right parties used the silence strategy. Only two army-related lawmakers were against the $\mathrm{CNV}$. While recognizing the importance of the committee's final report, most (left-wing) parliamentarians considered the work insufficient because the commission was based on the search for truth and memory, but avoided doing justice by punishing the torturers.

\section{LE DÉBAT PARLEMENTAIRE SUR LA COMMISSION NATIONALE DE LA VÉRITÉ AU CONGRÈS NATIONAL BRÉSILIEN}

\section{Antonio Teixeira de Barros}

Mots-clés: Commission nationale de la vérité; Mémoire politique; Droits de l'homme; Congrès national; Discours parlementaires.

Cet article analyse le débat parlementaire au Congrès national brésilien sur la Commission nationale de la vérité (CNV), depuis la présentation du projet de sa création en 2011 jusqu'à la conclusion de ses activités en 2014. Le corpus comprend 512 déclarations, 416 des députés et 96 des sénateurs. Le cadre théorique est axé sur des études de politique de la mémoire et de la justice transitionnelle. Dans le débat, la voix de la gauche a prévalu, favorable à la $\mathrm{CNV}$, tandis que la droite a eu recours à la stratégie du silence. Seuls deux législateurs liés à l'armée se sont manifestés contre la CNV. Tout en reconnaissant l'importance du rapport final de la CNV, la plupart des parlementaires (de gauche) ont jugé le travail insuffisant, car la commission était guidée par la recherche de la vérité et de la mémoire mais ne pouvait pas rendre justice en punissant les tortionnaires. 